\title{
INTERPRETATION OF FUNDAMENTAL RIGHTS IN THE CZECH REPUBLIC
}

DAVID SEHNÁLEK

\section{Brief Introduction of the Czech Constitutional Court}

This chapter aims to describe the position of the Czech Constitutional Court (hereinafter, 'the CCC') in the system of public authorities of the Czech Republic, and highlight those aspects of its functioning that are relevant for the manner in which this authority interprets the law, how it argues, and what decisions it makes. The chapter will focus on those matters that are reflected in the formation of this authority's will and that affect the contents of its decisions.

The CCC is an institution independent of other authorities in the Czech Republic, in terms of both organisation and financing, ${ }^{1}$ and performs the function of concentrated constitutional justice. ${ }^{2}$ This competence is 'originary' in nature and relies directly on the Constitution, where it is also defined. It can be neither extended nor reduced by statutory (i.e. sub-constitutional) law. The Court's task is to ensure constitutional balance and serve as a safeguard of democratic functioning of the State and of citizens' constitutional rights. The Court is undoubtedly succeeding in this role. As a body of the judiciary, it should technically be apolitical, but it does somewhat engage in practical politics; ${ }^{3}$ it is confident, assertive, and often not

$1 \mathrm{Pl}$. US 11/02 (judgement on independence of judges - salaries).

2 This follows from the nature of the matter and is legally regulated.

3 In practice, the Court is at times referred to as the third chamber of the Parliament, Pl. US 1/08 and Pl. US 2/08. 7 Novak, 2001, p. 422.

David Sehnálek (2021) Interpretation of Fundamental Rights in the Czech Republic. In: Zoltán J. Tóth (ed.) Constitutional Reasoning and Constitutional Interpretation, pp. 245-299. Budapest-Miskolc, Ferenc Mádl Institute of Comparative Law-Central European Academic Publishing. 
actually self-restrained in this regard. ${ }^{4}$ When saying this, I refer especially to the way the CCC proceeds towards other authorities in the Czech Republic, especially the Government and the Parliament, ${ }^{5}$ and also towards the Court of Justice (hereinafter, 'the ECJ). ${ }^{6}$ It takes advantage in this regard of the fact that no remedy is available against its rulings, and the CCC also seeks to avoid any potential changes to the legislation that could ultimately restrict its reach. Its line of defence is twofold: it rejects any formalistic approaches to the functioning of public administration ${ }^{7}$ and works with the 'material core' of the Constitution.

The CCC is competent to act in cases defined by the Constitution, and the applicable rules do not enable it to initiate proceedings without a motion (ex officio). The locus standi is defined separately and differently for each individual type of proceedings; in general, an application to initiate proceedings may be filed by private individuals, juristic persons, ${ }^{8}$ and public authorities. ${ }^{9}$ An actio popularis is not admissible. ${ }^{10}$ The CCC cannot refuse to hear a case if the statutory conditions for hearing the case are met.

The CCC has traditional powers typical of constitutional courts. It plays the role of a negative legislature, ${ }^{11}$ ensures ex ante control of international treaties, conducts proceedings in matters concerning elections and the Parliament, and has the power to rule on constitutional complaints. There are three types of such complaints, namely, general, municipal, and based on a motion filed by political parties. A general complaint is aimed against a final decision or other encroachment by public authorities interfering with constitutionally guaranteed fundamental rights and freedoms according to Art. 87 (1)(d) of the Constitution.

The CCC ensures the enforcement of fundamental human rights and freedoms in the Czech Republic, but it is not the only institution to perform this task. This protection is also and in fact primarily provided by the common courts. The consequence is that proceedings on constitutional complaints strictly adhere to the principle of subsidiarity.

4 See Pl. US 26/11 (Planned home births decision).

5 For further analysis, see Dumbrovský, 2013, pp. 69-70.

6 CCC was the first Constitutional Court in the EU to rule against the previous decision of the ECJ.

7 The CCC has prevented the constitutional legislature from modifying the constitutional order through a constitutional law despite lacking the competence to review constitutional laws. It circumvented this conundrum by stating that the regulation in question was a constitutional law only on paper but not in its substance. Pl. US 27/09 (shortening the term of the Chamber of Deputies by a one-off constitutional law judgement).

8 Both must be represented by a lawyer.

9 However, an administrative authority, whose decision has been successfully contested by an administrative action, lacks the standing (locus standi) to file a constitutional complaint against the decision rendered later by the administrative court, Pl. US-st. 9/99 no. 1; meanwhile, if the State and its bodies are in a position analogous to private individuals, i.e. in those cases where they are a party to a private-law dispute, they may file a constitutional complaint. III. US 651/05.

10 I. US 462/03.

11 A law (statute) that is contrary to the Constitution is annulled, and the CCC, therefore, does not declare it null and void. Annulment serves as the last resort; in practice, preference is always given to seeking an interpretation that conforms to the Constitution; Pl. US 45/04. 
The CCC stands outside the system of common courts and is not authorised to supervise the decision-making of such courts or act as another instance within their structure..$^{12}$ However, the CCC does not always strictly adhere to this restriction, and one can thus encounter cases where a decision is made by the CCC on the merits of an individual case. ${ }^{13}$ The CCC does not unify the Czech courts' case law-this is up to the two supreme courts. ${ }^{14}$ Furthermore, unlike its predecessor-the Federal Constitutional Court of the Czechoslovak Federal Republic-the CCC lacks the power to provide legal interpretation of the law. Nonetheless, the way the CCC approaches the issue of the binding effects of its case law relativises the absence of this power.

The CCC's decision-making is significantly influenced by its internal structure. The CCC is composed of a total of 15 justices appointed by the President of the Republic; two of them serve as vice-presidents of the Court and one has the position of president. Professional judges and experts outside the judiciary may be appointed as justices of the Court. This, in turn, affects the Court's decisions because a former attorney-at-law or law professor would have specific views on occasion and they might rely on values that a professional judge would neglect. ${ }^{15}$

The CCC is always the one to pronounce rulings vis-à-vis third parties. It is distinguished, however, whether an individual decision is rendered by an individual panel or by the Plenum. ${ }^{16}$ In cases where the Court rules in the Plenum, the decision is formed by all its justices. The Court has four three-member panels. Their composition changes regularly every two years according to a system of gradual rotation. This rotation of justices is relatively novel to the Czech Republic and helps align the potentially differing views of the individual panels. This setup contributes to a greater consistency in decision-making by the CCC as a whole,${ }^{17}$ while also enabling the individual judges to share their views and values. Overall, however, the CCC is a stable body, also because the justices are eligible for re-appointment. Given the term in office (10 years) and the fact that all the justices of the newly established CCC started their term at the same time after the inception of the independent Czech Republic, one can distinguish the individual 'generations' of CCC justices and discern the influence of the individual Presidents of the Czech Republic who appointed them.

The present work problematises the high number of small panels of justices in the context of the functioning of the CCC. Justices are personages with various opinions

\section{I. US 481/04.}

13 A clear example is the Consumer decision, II. US 2778/19.

14 I. US 272/02.

15 Former Justice Wagnerová and current Justice Šimáčková prove my point. Although they originally came from outside of the judiciary, both have been very influential justices and often made quite unorthodox decisions.

16 Certain cases may also be decided by individual justices. Indeed, the justice rapporteur has the authority to reject him/herself an application to initiate proceedings.

17 Those who are familiar with the internal affairs of the Constitutional Court can identify which justices share similar views and are thus able to effectively influence the rulings made by an individual panel. 
and philosophical attitudes towards the law and politics. ${ }^{18}$ The methods of work in individual panels, their lines of legal argumentation, as well as the ways they treat foreign sources, including the case law of the ECJ and the European Court of Human Rights (hereinafter, 'the ECtHR), differ substantially among the panels. ${ }^{19}$ These differences are also clearly apparent in the wording of the individual decisions. ${ }^{20}$ Even the legal conclusions of the individual panels can differ ${ }^{21}$ in the sense that one can guess, with some degree of probability, how a certain panel will decide on certain questions, while knowing that another panel would most likely make a different ruling. ${ }^{22}$ This is one of the main issues related to the functioning of the CCC. If the individual panels were composed of a higher number of justices, then their decisionmaking would probably be more consistent.

Each panel is managed in organisational terms by one of its justices, the presiding justice; however, this position entails no special influence on decision-making. The role of justice rapporteur is much more important in this regard. All members of a panel are completely equal; two judges agreeing on a certain decision is sufficient for such a decision to be upheld. This small number is not enough in view of the significance of the CCC's rulings. However, an argument pointing out the effectiveness of decision-making in small panels has prevailed. ${ }^{23}$

The drawbacks of small panels are offset by the fact that the most important types of proceedings are mandatorily conducted in the Plenum. The Plenum ensures primarily constitutional control of statutory and secondary laws, and may decide on the annulment of laws (statutes) and other legal regulations, as well as their individual provisions. ${ }^{24}$ Furthermore, it may decide upon a constitutional charge

18 The President of the Republic can exercise an indirect influence on the Court's decisions, as he/she has the power to appoint justices for a term of 10 years (with the consent of the Senate). Therefore, the President's choice of justices pre-determines the opinions of the CCC in the coming period.

19 However, even inside a single panel, the person appointed as justice rapporteur in an individual case holds a position of importance, as he or she shapes the formal aspects of the ruling, i.e. determine how the decision will be viewed from the outside.

20 It has to be emphasized that the criteria based on which decisions were chosen for this study were set in such a way that not all the aspects of the CCC's decision-making could be fully revealed.

21 The Plenum plays the unifying role under Section 27 of the Act.

22 The general rule in the decision-making in panels is that they make decisions by a simple majority, i.e. it is sufficient if two judges agree on a certain solution. This is indeed quite inadequate in view of the importance of certain decisions for everyday life and given the political role of the CCC. The whole problem may be demonstrated in case II. S 3212/18, which was de facto decided by two justices in such a way that Pavel Rychetský, the President of the "CCC Cour"t (sic), declared this decision to be wrong. He also said that he is ashamed of it and, most importantly, that this decision should not be followed. Such criticism is exceptional and surprising, especially considering the position of its author and the fact that the decisions of the CCC are binding on both the common courts and the CCC itself. However, such fundamental disagreements between judges are rare and do not often occur. In terms of statistics, most decisions on constitutional complaints are taken unanimously. In any case, for me, the decisions of the CCC to have the widest possible consensus is a matter of fundamental importance.

23 Fast and cheap do not necessarily mean correct and generally acceptable in society.

24 Pl. US 24/94. 
brought by the Senate against the President; a petition by the President seeking the annulment of a concurrent resolution of the Assembly of Deputies and the Senate; disputes over whether a decision to dissolve a political party or some other decision relating to the activities of a political party is in conformity with constitutional acts and with statutes; remedial actions from a decision of the President declining to call a referendum on the Czech Republic's accession to the EU; disputes over whether the manner in which the referendum on the Czech Republic's accession to the EU was held conforms with the Constitutional Act on the Referendum on the Czech Republic's Accession to the EU and with the statute issued in the implementation thereof; other matters if a panel has not resolved them in the case of a proposed resolution not receiving a majority of votes; the determination of the Court's position on a proposition of law that differs from a proposition of law announced by the Court in a previous judgement; petitions for rehearing of a proceeding and such reopened proceedings; and the regulation of its internal relations; the establishment of Panels and the rules for the distribution of the caseload among them. The Plenum may also reserve for itself cases that could otherwise be decided by a panel. The Plenum also decides on motions to assess conformity of an international treaty with the constitutional order.

The Plenum's decision-making may include up to three tiers to achieve a compromise; no such procedure is required in panels and is therefore not regulated. In principle, every justice (in the Plenum and in a panel) can present their own proposal of how a case should be resolved on its merits. ${ }^{25}$ Vote is taken on the operative part, but not on the reasoning. The justice rapporteur's position is typically very strong as they can clearly influence the contents of a decision, ${ }^{26}$ especially in terms of its reasoning. ${ }^{27}$ At the same time, the practice is to vote on their proposal first. In regular cases, a decision is adopted by a majority of justices (the quorum is 10 justices); a qualified majority of nine justices is required in some more important cases.

Matters falling within the competence of the Plenum and panels are assigned automatically, according to fixed and predetermined rules. In the first assignment round, one case is assigned to each justice, including the officials of the Court, based on the date of receipt and in alphabetical order of the justices' surnames. The Court president and the two vice-presidents are then left out in the second assignment round.

The specific role played by the justice rapporteur has already been mentioned above. The significance of their role in proceedings before the CCC is described in more detail as follows. The justice rapporteur has a substantial influence over the decision-making of the CCC, as well as the form, contents, and reasoning of its

25 In disputes concerning individual rights, the specific right violated is identified (if a right is found to be violated).

26 Chmel, 2017, p. 757.

27 The justice rapporteur predetermines not only the reasoning but also the success of the complaint. For example, former Justice Eliška Wagnerová was known for her willingness to rule in favour of the complainant statistically significantly more than any other judge. Chmel, 2017, p. 740. 
decision. What is important for this chapter is primarily their task to prepare a draft decision, together with substantiation of the solution chosen. If the rapporteur's proposal is adopted, they will also be asked to draw up the decision itself. The practice is that members of a panel often follow the opinions and conclusions of the justice rapporteur. This, de facto, amounts to an unofficial and informal authorisation of the judge to resolve the case, as the other judges accept the chosen solution without further considerations. ${ }^{28}$ This is a matter of the judges' personal choice and confidence in the justice rapporteur's integrity and knowledge.

However, the justice rapporteur can also exert a substantial influence over the contents of a decision based on other factual reasons. Indeed, if their work is timed right, the other judges may be unable to interfere realistically and effectively with the contents of the decision. For example, in the recent case of annulment of the Elections Act (a decision of extraordinary importance, for a number of reasons), the justices received the first version of the decision on Thursday, 21 January 2021, and discussed the proposal (together with five other proposals) on Tuesday, 26 January 2021; the full judgement was then pronounced 19 hours after its adoption, without the justices having been provided with its final version. Therefore, there was little time to prepare quality objections against the reasoning or express a differing opinion, which the outvoted justices did not forget to mention in their dissenting opinions. Such settings should be changed. ${ }^{29}$

Invisible from the outside but nonetheless considerable influence over the functioning of the CCC can be wielded by assistants to individual justices ('assistants'). Three assistants support each justice in their work. ${ }^{30}$ Based on the law, assistants perform tasks unrelated to direct decision-making. They may, for example, reject documents that objectively lack the nature of a pleading to the Court. However, their role is, in fact, more important than might seem. Reality thus considerably differs from what is cautiously defined in the law. Indeed, the scope of the assistant's work is de facto very broad. This will naturally depend on the given justice and on how much they are willing to delegate to their assistants. Constitutional justices are asked to perform a great amount of work, not to mention their possible parallel lecturing at universities. The assistants' role is thus significant and they are often the ones who draft decisions and formulate the reasoning in cases where the justice serves as the justice rapporteur. ${ }^{31}$ Assistants' work may not be so apparent from the outside; they work for the justice while formally lacking the position of a judge. Justices make all their decisions in their own name, and are also responsible for them. Ideally, it should be the justice who sets the strategy in a case and pre-determines the decision. The result should then either be achieved based on what the assistants prepare for

28 Chmel, 2017, p. 744.

29 Such cases are not rare. In case Pl. US 26/11, the majority of judges (nine) were against the reasoning of the decision, yet they could only express their opinion via their concurring opinions.

30 This refers to a full-time equivalent; the number of assistants may be higher.

31 Wagnerová, 2007, § 8. 
the justice, or the justice should directly specify what underlying documents the assistant should prepare so that these support the result at which the judge intends to arrive. Assistants and justices might influence each other, or the general concept of a decision might be drafted by an assistant ${ }^{32}$ and then affirmed by the justice. It is also not unusual for assistants to hold high positions in academia. Some of them are associate or full professors of law and their qualifications are absolutely comparable to those of the justices. ${ }^{33}$

Justices may also informally involve student interns in their work. However, it is again up to each justice whether they will hire an intern and to what degree they will accept or let themselves be influenced by the results of the intern's work. It might seem that a student will lack the necessary qualifications and experience to be able to contribute significantly to the Court's decision-making. It is a fact, however, that interns are usually talented students who are chosen and addressed by a justice based on their results at school. The involvement of assistants and interns increases the plurality of opinions in proceedings before the CCC, which partially relativises the above objection to the inadequate number of justices in individual panels.

Finally, in terms of the institutional prerequisites for decision-making by the CCC, one should also recall the role of the analytical department. The Czech Republic is part of the Venice Commission. The analytical department makes use of this fact and, where relevant, prepares reports on the foreign legislation and case law. Its activities are not always discernible in the decisions of the CCC, but the factual influence of foreign laws is nonetheless considerable (in the Czech Republic, a key role is played especially by Austrian and German laws). Thus, what can actually be seen in the CCC's decisions does not fully reveal the background and all the reasons that lead to any given decision.

The plurality of views is further highlighted by a justice's right to express a differing opinion (both dissenting and concurring). A differing opinion on a case can be expressed both with regard to the operative part and to the reasoning of the decision. It can be attached to decisions of both a panel and of the Plenum. It has no legal consequences as such. ${ }^{34}$ It reveals what discussions preceded the decision, what alternative arguments were presented, and what solutions were considered, and how 'firm' the decision actually is. It can also serve as a basis for further development of case law. ${ }^{35}$ The ratio of votes for or against a certain decision need not be published.

32 The usual procedure is that the justice assigns a case to a certain assistant, who then draws up a draft decision; the justice reads it and presents it to his or her other assistants, who are asked to provide their opinions.

33 Moreover, it must also be emphasized that the justices themselves pick their assistants; it can be assumed that the proverb 'birds of a feather flock together' may apply here in terms of worldview.

34 Its form is also not prescribed in any way and thus differs significantly among individual justices. For example, Emeritus Justice JUDr. Balík was known for his original and unorthodox opinions, which were often very concise, and his reference to classical literature. His opinions did not comprise any legal analysis but, nonetheless, often indicated how he viewed the resulting decision.

35 Pl. US 42/2000. 
However, the concept of differing opinions indicates what opinions the individual justices held.

From a procedural point of view, the CCC's activities correspond, in principle, to the procedures at common courts. There are some deviations, which ensue from the mission of the CCC as defined by the Constitution. In its decision-making, the CCC is bound by the relief sought in the application to initiate proceedings, rather than by its substantiation, ${ }^{36}$ which gives the Court a broad space for assessing the given matter. Similarly, the CCC is not bound by the evidence adduced, and may take other evidence of its choice. Nonetheless, the CCC typically does not take evidence, as it is not considered a common court. ${ }^{37}$ Therefore, evidence taken by common courts is not reviewed here. Where the CCC takes evidence, it does so basically only in specific proceedings, such as in the case of a constitutional complaint, to verify the complainant's assertion that their fundamental rights and freedoms have been violated. It is generally not necessary to take evidence regarding the merits of a case. Overall, the CCC deals with general, legal questions, where it would make no sense to take factual evidence.

For the purposes of this chapter, it is also essential to clarify the status of international treaties in Czech law and, in turn, the relation between the CCC and the two European courts, namely, the ECtHR and ECJ. According to the current regulation in Article 10 of the Constitution, the relation between Czech and international law is of mixed nature. It is a dualist relation with significant monist elements. While the two legal orders are separate and independent, the Constitution states that selected international treaties form a part of the laws applicable in the Czech Republic. ${ }^{38}$ They are thus automatically directly applicable, taking priority over ordinary laws (statutes). However, as an external source of law, they have no greater legal force than Czech laws; the relation between them is merely one of application.

International treaties on the protection of human rights and freedoms have a special status in Czech law. They are considered a part of the constitutional order and serve as a benchmark in assessing the constitutionality of ordinary laws (statutes). Further, the Constitution provides in Art. I (2) that the Czech Republic shall observe its commitments resulting from international law. This provision is reflected in the area of interpretation; a line of interpretation that is generally consistent with the external commitments of the Czech Republic is strictly preferred. The Constitution does not provide for the relation between EU law and national law; this, however, is not considered an issue. In contrast, the principles of application of EU law are laid down by the EU law itself. The CCC is generally forthcoming towards EU law.

$36 \mathrm{Pl}$. US 47/04.

37 Therefore, it is not a third instance in the structure of common courts; it does not deal with a violation of regular rights of natural or juristic persons protected by general laws, unless the case also involves a violation of a fundamental right or the freedom of these persons, guaranteed by a constitutional law or an international treaty, I. US 108/93.

38 This is why it is often stated, in simplified terms (but not entirely correctly), that the relation between international and national laws is monist in the Czech Republic. 
One substantial difference can be inferred from the above in terms of how the CCC approaches interpretation of international treaties and that of EU law. The CCC does not hesitate to interpret international treaties providing for human rights, and has no problem admitting this. Meanwhile, it refuses to interpret EU law openly as according to the CCC, 'Community law is not part of the constitutional order and, therefore, the Constitutional Court is not competent to interpret it. Nevertheless, the Constitutional Court cannot entirely overlook the impact of Community law on the creation, application and interpretation of national law in the area of legal regulations whose creation, effect and purpose are directly linked to Community law (...) However, the two supreme courts are the ones within the system of ordinary courts that ensure the consistency of judicial decisions in the Czech Republic within the scope of their statutory competences'. ${ }^{39}$ Consequently, while international treaties on the protection of human rights have a constitutional nature, EU law is sub-constitutional and thus outside the interest of the CCC.

In reality, however, even the CCC is forced to interpret EU law, as this is often a prerequisite for correct interpretation and application of Czech law. ${ }^{40}$ The CCC has showed a relatively forthcoming approach, as apparent, for example, from the way it has construed the Charter and possibility of extraditing a Czech citizen abroad. Instead of a simple and restrictive linguistic approach to interpretation, the CCC prioritises Euro-conforming interpretation. The CCC also accepts the German doctrine of 'radiation', ${ }^{41}$ In this concept, EU law radiates into Czech law and thus influences its interpretation..$^{42}$

As regards the 'judicial dialogue' and the role of the CCC in this dialogue, it is necessary to distinguish between the CCC's approach towards the ECtHR, on the one hand, and the ECJ, on the other hand. In summary, in the case of the ECtHR, one cannot speak of any dialogue in the true sense of the word. The CCC simply accepts its decisions and, where necessary, ensures their application. It does so even in cases where it has previously made a different decision. There are no discrepancies between the case law of the ECtHR and that of the CCC; there are no differences in opinions or, at least, no such differences are apparent. This probably also owes to the fact that the Charter protects rights that are also protected by the European Convention. There is not much room for conflict. The CCC's approach to ECtHR case

39 II. US 1009/08.

40 This is confirmed, e.g. by decision II. US 3432/17: '[t]he Constitutional Court's aim in these cases is not, however, to look for the correct application of [the] EU law or even to interfere with the competence of the Court of Justice by authoritatively interpreting the contents of the EU law, since the Constitutional Court examines exclusively whether the application of the EU law by common courts was arbitrary or unsustainable'.

41 In its sugar quotas decision, the Constitutional Court concluded that it would 'examine the legal key to distribution of production quotas in terms of national constitutional law interpreted in the light of Community law'.

42 This effect of the EU law on the national law is referred to as 'radiation' in judgements of the Constitutional Court and closely resembles the German notion of 'Drittwirkung'. See also Zemánek, 2016, p. 91. 
law can be divided into several groups. First, ECtHR case law is used in some cases basically as a source of law and the case at hand is assessed on its basis. Second, it can be used to explain the contents of Czech law. Third, it is also used as a parallel supporting argument for resolving a certain matter. However, this is not to say that the CCC would always subject itself to ECtHR case law, and that it would decide each case identically as the ECtHR. For example the test of assessing for a violation of the right to privacy differs between the CCC and ECtHR..$^{43}$ In the marginal case of Smatana, the CCC failed to accept the European ruling ${ }^{44}$ and stated its explicit disagreement with the conclusions of the ECtHR. ${ }^{45}$ In general, the CCC is not showing any tendencies towards analysing and discussing ECtHR case law in greater detail, and mostly adheres to it.

The relation between the CCC and the ECJ is different. Indeed, the ECtHR is generally not viewed as a competing court. Such an attitude can, however, be seen on the part of the CCC towards the ECJ. Moreover, the ECJ often uses different criteria in its decision-making compared with the CCC and ECtHR, as its focus goes beyond the protection of human rights. ${ }^{46}$ This is manifested in several ways. First, emphasis is placed, as already mentioned above, on the constitutional mission of the CCC and general perception of EU law as sub-constitutional law. Second, the CCC refuses to enter into a formal dialogue with the ECJ by requesting its preliminary ruling in a case. The CCC has not expressly excluded the option of making such a reference, but it has been systematically avoiding it. This does not mean, however, that it would generally adopt an anti-EU stance. Indeed, it consistently requires that the duty to refer questions for a preliminary ruling be adhered to by common courts, and construes a failure to do so as violation of Czech constitutional law. A dialogue with the ECJ is thus imperative, but has to be conducted by other courts, not by the CCC. No problems generally arise as regards the acceptance of the ECJ's case law and its interpretation of EU law. The only, albeit major, exception is the case of Holubec, where the CCC, as the first supreme court of a Member State, refused to accept the conclusions formulated in a prior judgement of the ECJ. The Czech Court assessed the case

43 The Czech national report to the XVIIIth Congress of the Conference of European Constitutional Courts, p. 15.

44 II. US 2395/09, where it was stated: 'In spite of the Court's disagreement with the conclusions made by the European Court of Human Rights in the case of Smatana v. the Czech Republic ..., where the Constitutional Court was descried as a remand court (using this logic, the ECtHR itself could be considered a remand court), it can be agreed that all governmental authorities have the duty to ensure a defendant is not remanded in custody longer than reasonable (Section 102). In addition, it follows from settled case law of the Constitutional Court that, as a rule, all remand cases are dealt with preferentially and even without a motion, because of the quality of the fundamental freedom concerned in such a case, i.e. personal freedom limited by the remand in custody. There is no reason to change this practice and the case at hand was therefore found urgent and the constitutional complaint heard preferentially'.

45 However, there was no actual conflict in this case because the constitutional complaint was found unjustified.

46 See the Austrian decision. 
and ruled in a different way than the ECJ previously did. However, this decision is an exception from the otherwise generally pro-European case law of the CCC.

The present work aims is to analyse, compare, and subsequently evaluate the manner in which national constitutional courts interpret fundamental rights. The analysis considers two aspects to be significant from this point of view. First, how does the CCC itself define the methods of interpreting the law (i.e. how should it be interpreted)? Second, we need to examine the reality (how the law is, in fact, interpreted). The aim of this chapter is to examine how the CCC carries out the application and interpretation of fundamental rights, as well as which methods of interpretation are preferred by this court. The chapter will also focus on its decision-making style. To objectify the conclusions and put them into a broader context, the research has selected decisions in which the court worked with ECHR and ECJ decisions (as the condition of the research design). In a second step, the decisions of these international courts are briefly analysed. The result will be a systematic comparison of the interpretative methods of these international courts with those generally used by the CCC in those cases that contain a substantive reference to ECJ or ECtHR decisions.

\section{The CCC and its definition of the methods of interpreting the law}

As regards interpretation of the law by the CCC, we have to bear in mind the special nature of the Constitution and the Charter. Both these sources of law contain general provisions rather than specific instructions and solutions. This implies that grammatical (textual) interpretation will have a limited weight in this field of law (legal basis). Emphasis must also be placed on the above-described position of the CCC as an authority that, in substance, is not subject to any external control and can only be limited by the case law of the ECtHR and, to some extent, of the ECJ. However, the CCC is not subordinate to any of these courts in terms of institutional basis. This fact implies a considerable freedom for legal considerations and decisionmaking. The CCC can take into consideration moral values, 'people's stories', political arguments, and further aspects that are out of reach for ordinary courts. The latter are bound primarily by hard law and the room for their discretion is limited. Finally, during the first decade of its existence, the CCC had to deal with the fact that a part of the Czech law had been adopted basically unchanged from the totalitarian era but nevertheless had to function in an environment based on different values (historical basis). ${ }^{47}$

Thus, the CCC itself shows a reserved attitude towards the grammatical (textual) method of interpretation. The CCC perceives the worth of this method only in the 
initial examination of the legal norm being applied. For the CCC, it is only the starting point in explaining and clarifying its sense and purpose, which is also the aim of a number of other procedures, such as logical and systematic interpretation and interpretation e ratione legis. ${ }^{48}$ The CCC has not specified any order in which these methods should be used; this will always depend on the circumstances of the specific case under scrutiny. What is apparent, however, is the great significance carried by teleological interpretation. As regards linguistic interpretation, the CCC has not hesitated to rule even contra verba legis in specific cases. ${ }^{49}$ Along with teleological interpretation, considerable weight is attributed to comparative interpretation of constitutional law. The emphasis on these two approaches to interpretation is so apparent that some (influential) justices of the CCC have concluded that the interpretation of constitutional law is a specific discipline that differs from that of sub-constitutional norms. The CCC's decisions do not show that the Court would clearly distinguish between the procedure in interpreting Czech (i.e. national) law and international treaties on the protection of human rights and freedoms (although these are formally a source of international law and this law sets its own methods of interpretation). This is quite paradoxical because differences tend to be highlighted inside a single system of law and, at the same time, overlooked with regard to different systems.

\section{Reality of interpretation of law by the CCC (2011-2020)}

The choice of judgements is not completely representative and does not provide a comprehensive view of the work carried out by the CCC. There are several reasons behind this and they all closely relate to the conditions set by the research design and to the characteristics of the CCC's work and of the individual justices. Both these facts predetermined which decisions would be chosen for assessment. The following factors played a role in this regard.

First, the style of the CCC's work differs depending on the field where it is called on to make a decision. Differences are apparent especially in the area of human rights and freedoms, on the one hand, and in constitutional matters (in the narrower sense of the word), on the other hand. We shall look into these differences in more detail in the part dedicated to the individual methods of interpreting the law.

Second, this research was designed to reflect those decisions that cite rulings of the ECtHR or the ECJ. However, the willingness of individual justices to work with these decisions varies considerably. ${ }^{50}$ As pointed out previously, the justice

$48 \mathrm{Pl}$. US 33/97.

$49 \mathrm{Pl}$. US 66/04 (European arrest warrant decision).

50 One can easily notice that Justice Kateřina Šimáčková most often use the case law of the ECtHR. She was a member of the panel in more than half of the 30 individual panel decisions that we selected. 
rapporteur has considerable influence on the contents and substantiation of individual decisions. The research design thus better suited those justices who are more open to external influences and who reflect more on the case law of the ECJ and the ECtHR in their decision-making (or perhaps, more accurately, they admit openly that they employ these sources). Their rulings are thus more frequently represented among the 30 decisions chosen. This does not imply, however, that other justices would perhaps completely overlook the case law of the ECtHR or the ECJ. The fact is that we are unable to determine from the reasoning of their decisions whether or not their case law was considered. Thus, the influence of the ECJ and ECtHR and their decisions could be greater than might appear from the CCC's case law; we simply do not know. ${ }^{51}$ Such an approach could be part of a strategy followed by this court. Silence is especially practical in cases where the conclusions made by the ECJ or ECtHR are not found satisfactory. Rather than acknowledging a conflict, it seems more appropriate to avoid it by not admitting its existence openly.

Third, the project aimed to choose the 30 most important cases over the past 10 years of the CCC's work. Admittedly, in view of the limitation to the area of human rights and the requirement of a substantive reference to ECJ or ECtHR decisions, the rulings chosen are a selection from a selection. The research attempted to render as objective the inherently subjective approach to the choice of the 30 most important decisions by intentionally opting for those that had caught the attention of the professional public. The selection thus focused on rulings dealing with socially important questions that resonated with professional publications or increasingly popular web blogs.

This selection of decisions yielded one substantial conclusion. Anyone who should perhaps expect the CCC's decisions chosen here to show state-of-the-art legal interpretation and legal arguments used in the Czech Republic will be disappointed. In fact, the opposite is true. Rather than a tribunal mastering the art of legal interpretation and using utmost diligence and precision, the CCC is primarily a political court. Interpretation of the law and its methods are somewhat sidelined in its work. They are not the primary instrument used by this tribunal to achieve its objectives. On the contrary, a number of decisions under scrutiny give the impression that interpretation of the law is merely an instrument retroactively justifying a pre-determined conclusion. It has to be admitted that this conclusion probably fits better the decision-making of individual panels but not the rulings devised by the Plenum.

The initial premise is that the methods of interpretation used by the CCC for interpreting the Charter and the Constitution should be the same as those used to interpret Czech sub-constitutional law. Indeed, there is nothing in Czech law that would indicate the opposite. What can differ, however, is the degree of consideration given to these methods in individual cases.

51 I am reluctant to infer simple conclusions along the lines of the ECtHR case law being neglected in a certain ruling just because it was not mentioned. 


\subsection{Grammatical (textual) interpretation}

Unlike in cases dealt with by the CCC with regard to state organisation issues, competences of state bodies and the status of constitutional organs, grammatical interpretation is basically only a marginal method in the area of fundamental human rights and freedoms. ${ }^{52}$ While the CCC itself calls it euphemistically a starting method, this often translates in practice into free discretion as to the contents of the relevant right or freedom.

The meaning of the words used by the Charter (interpretation based on ordinary meaning) is thus not examined in any way. Their substance is probably taken into consideration at some elementary level, but this is not explicitly admitted in the individual decisions. The entire process often probably takes place subconsciously.

Interpretation based on the ordinary meaning of words does not represent a frequent method of interpretation. On the contrary, from a purely statistical perspective, legal professional (dogmatic/doctrinal) interpretation is the frequently used type of legal interpretation in decisions of the CCC, deployed in 17 cases. The more frequent occurrence of this method does not change the fact that this method of interpretation is not a decisive one.

The reason for this restrained approach towards interpretation based on ordinary meaning lies in the general concept of the Charter, which creates a favourable environment for such an approach. ${ }^{53}$ However, the CCC has no reason to defend its steps by means of grammatical reasoning (which is less questionable compared with other methods of interpretation) as its conclusions cannot be reviewed. Emphasis on the actual legislative text may be characteristic of the lowest instances of the Czech judicial system. Referencing the wording of the law is an intellectually undemanding exercise and, at the same time, relatively safe way of justifying one's decision. The risk that the appellate instance will overturn conclusions solidly based on grammatical interpretation is relatively marginal.

Meanwhile, such an approach would be beneath the Court's dignity. It can be stated with slight exaggeration that grammatical interpretation is not considered 'sexy' enough in the Czech Republic. Throughout the 1990s, the CCC repeatedly emphasised that sticking excessively to the wording of the law was formalistic, obsolete, and outdated. This was a response to mechanical approaches to interpretation forming a legacy of socialist law. The CCC came closer to courts serving as its role models in terms of the way of thinking, interpretation, and

52 Kühn also pointed out the practical non-use of this method of interpretation. In cases of fundamental rights, the CCC often does not recite the provision concerned; instead, it follows an existing case law, Kühn, 2017, p. 215.

53 The conclusions applicable to the interpretation of the Charter cannot be excessively generalised. Grammatical interpretation is important in the CCC's case law in competence matters regulated by the Constitution. 
arguments. ${ }^{54}$ Indeed, these courts issued a number of their decisions in cases where textual interpretation was only ancillary. The decisions selected here do not show any genuine search for a plain, literal, and ordinary sense of the terms used. ${ }^{55}$

The general approach to fundamental rights regulated by the Charter is that the CCC simply and plainly notes the existence of such a right and the possibility of its impairment in the case at hand. The contents of the right are then clarified using other methods of interpretation, and these contents are provided (complemented) especially through ECtHR case law or references to previous rulings of the CCC. Where several rights are affected at the same time, the CCC directs its intellectual capacity in the decisions under scrutiny, especially towards balancing these rights. Emphasis is generally placed on the test of proportionality or rationality.

Nonetheless, there is one case in the set under scrutiny where the Constitution offered no provisions whatsoever on which the CCC could rely in its conclusions. ${ }^{56}$ The CCC thus made its decision without a legal basis. It simply devised a certain result and, in substance, filled a lacuna in applicable law; however, by doing so, it de facto assumed the position of legislature. It did not consider the fact that elements not regulated by the law would impede decision-making, although it cannot play the role of active legislature, and also despite the fact that this impaired the balance in the system of separation of powers in the State (Art. 2 (1) of the Constitution) as well as the principle that State power can only be exercised in cases within the limits and in the manners laid down by the law (Art. 2 (3) of the Constitution, Art. 2 (2) of the Charter of Fundamental Rights of Freedoms).

Finally, the set of decisions under scrutiny includes one where the CCC pragmatically and explicitly gave up on any attempt to interpret a certain relevant term. This was so in the case of electronic records of sales and the right affected was the right to protection of privacy. ${ }^{57}$ Indeed, the CCC states that ' $[t]$ he role of the Constitutional Court is thus to assess whether the provisions contained in the Electronic Records of Sales Act can stand in confrontation with protection of a tax entity's privacy and its right to self-determination in terms of information, precisely in view of its own case law and case law of the Court of Justice of the European Union'. It goes on to note, however, that 'it is neither possible nor necessary to try and find an exact definition of "privacy" or "private life". This is true especially because, with regard to

54 While the ECtHR is openly regarded as such a role model, the ECJ's self-confident and assertive decision-making serves as a more concealed and less frequent source of inspiration; the CCC's considerations and methods of work are also clearly influenced by common-law courts and their approach to interpretation of the law and judicial law-making.

55 A certain exception is a case where the CCC compared two concepts and stated that 'public service has the nature of dependent work within the meaning of Section 2 of the Labour Code, and can thus, beyond any doubt, be subsumed under the broader term of "work or service" within the meaning of Art. 9 (1) of the Charter'.

$56 \mathrm{Pl}$. US 36/17.

57 Pl. US 26/16. 
certain occupations, it is basically impossible to determine whether the given entity is working or living a private life at any given moment'. Balancing is thus carried out against a value that is not specifically determined. What is such a concept actually good for? The decision as such was based, in substance, on some sort of ad hoc subjective and highly generalised assessment of the given situation, and the concept of privacy and its definition were already neglected at the level of grammatical interpretation.

The CCC tends to rely more on the political subtext and relevant values than on the text of the Charter. The term 'values' refers to values advocated by both the CCC and the State, and even by individual justices. The CCC does not employ any uniform approach to grammatical interpretation of the Constitution based on subconstitutional law, either. This will be further analysed in the section dealing with domestic systemic arguments. It cannot be determined unambiguously based on the sample under examination whether there is any internal methodology, logic, and system in the linguistic interpretation carried out by the CCC (whether within the Charter or in relation to sub-constitutional law). This is in no way indicated in the CCC's decisions. There is no such internal methodology or it has yet to be systematically applied. Every decision is unique from this point of view. However, the values promoted by the individual justices often influence the contents of the law.

As regards interpretation of sub-constitutional law, the CCC exercises a much more restrained approach and works with the text of legal regulations. The grammatical method of interpretation is the first, basic, and common method of interpretation of the law. However, analysis of the selected cases was not supposed to focus on this aspect of the CCC's work.

\subsection{Logical (linguistic logical) arguments}

Arguments of this type have a considerable auxiliary significance in the interpretation of the law by the CCC but do not belong among arguments commonly used by the Court. This is also documented by the low individual occurrence in the set of 30 examined decisions. When expressed collectively, they may give the paradoxical impression of being frequent, as they have been used in 17 cases.

\subsubsection{Argumentum a minore ad maius}

Argumentum a minore ad maius plays an important role in a case concerning protection of privacy and family life with regard to the possibility of giving birth at home. The CCC has noted that, in view of its complexity and multi-layered reflection in the law, it cannot define exhaustively all the individual components of the right to protection of private life guaranteed in Article 8 of the Convention, let alone offer any specific individual procedural instruments for its protection. If such a situation occurs and a certain procedural remedy for the protection of the right to privacy is unknown in the law, then such a remedy must be provided a minore ad maius using a 
more general institution of protection of the right to privacy-the through protection of personal rights. ${ }^{58}$

In the same ruling, the argument of a minore ad maius is used with regard to the need to reflect ECtHR case law in proceedings before Czech courts. The Constitutional Court concluded that public authorities have a general duty to take into account interpretation of the Convention provided by the ECtHR. ECtHR decisions represent an important interpretation guideline for application of the Convention. The courts are thus obliged to take case law of the ECtHR into consideration in cases where the lawsuit is directed against the Czech Republic and in matters concerning another Member State of the Convention if, in view of their nature, these cases are also relevant for the interpretation of the Convention in the Czech context. This is all the more true in a situation where such case law is invoked by a party to proceedings before a Czech common court. If the court concerned fails to deal with the case law of the ECtHR, this may constitute a violation of the right to a fair trial. ${ }^{59 ; 60}$

\subsubsection{Argumentum a maiore ad minus}

In the set of selected decisions, the argument of a maiore ad minus is used for interpretation of both sub-constitutional ${ }^{61}$ and constitutional law. The situation is complicated by the fact that the CCC directly uses either the Latin designation of the relevant argument or its Czech counterpart (... this applies all the more to ...). This makes it difficult in some cases to distinguish the logic in the CCC's considerations and determine its direction, whether from the smaller to the larger, or the opposite. This was so in a situation where the CCC dealt with conditions under which interpretation of EU law is clear (acte clair). ${ }^{62}$ ECJ case law requires uniform interpretation of the law by courts of various Member States. The CCC is asked to answer the question of whether this condition could be met in a situation where courts in a single country make different decisions. In this case, the CCC states as follows: '[i] $\mathrm{f}$ a considerable margin of discretion in assessing the obviousness of interpretation of EU law by a common court is acknowledged by the European Union law, then this should apply all the more to the Constitutional Court, operating in a different reference framework for review. Therefore, cases where a common court proceeded arbitrarily when assessing the existence of acte clair can be considered a violation of the fundamental rights to a fair trial or a statutory judge. This may include two

$58 \mathrm{Pl}$. US 26/11.

59 A violation of the fundamental right to judicial protection pursuant to Art. 36 (1) of the Charter, Art. 6 (1) of the Convention, or the relevant fundamental right under the Convention, as the case may be. In any case, Art. 1 (2) of the Constitution is also affected.

$60 \mathrm{Pl}$. US 26/11.

61 Based on the argument of a maiore ad minus, if an employee, whose employment is about to end and thus lives in uncertainty about his/her future, needs four hours a week to exercise the right described above, all the more that 20 or more hours a week will suffice in this regard, Pl. US 1/12. 62 US 3432/17. 
situations, in particular: 1 . the court itself had (apparent) doubts as to interpretation of the EU law and did not refer a question for a preliminary ruling; 2 . although the Court of Justice had yet to resolve a similar problem of interpretation, the common court went beyond the margin of its discretion and interpreted the issue itself without referring a question for a preliminary ruling in the given case, in a manner that is clearly unsustainable'. This concept of interpretation of EU law and the role of the CCC in its interpretation implies that the CCC should not refer questions for a preliminary ruling in matters which it itself considers acte clair.

As regards the duty to refer a question for a preliminary ruling in case of different interpretations of EU law by various courts of instance in the Czech judicial system, the CCC considers two possible variants. First, a hierarchical approach will apply in the judicial system of one country and it is the court of last instance that will assess the obviousness of interpretation. Second, it can be stated a maiori ad minus that certain law cannot be acte clair if courts of the same country disagree on it. These clarify the direction of the Court's considerations. In the CCC's opinion, both these variants are possible and a mere linguistic interpretation is not sufficient to provide the answer. In the end, a solution based on the argument of a maiori ad minus was not applied; this was merely an alternative that was considered and was based on arguments presented by the parties to the proceedings. The CCC ultimately rejected it because the solution offered was not practical; there was another solution that was more cost-effective and efficient, and was also supported by ECJ case law.

In a decision concerning a general reduction of public prosecutors' salaries, the argument of a maiori ad minus serves the interpretation of the right to undisturbed discharge of public office under Art. 21 (4) of the Charter. Indeed, the CCC first dealt with the possibility of reducing the salaries of public administration staff in relation to the right to fair remuneration for work under Article 28 of the Charter. It then stated that if this specific right is not violated by the reduction of salary, then this certainly could not be true of the right to undisturbed discharge of public office.

\subsubsection{Argumentum ad absurdum}

This argument also appears only rarely in the set of decisions reviewed. The CCC refers to it in interpretations of sub-constitutional law, where it uses this interpretation to limit possible but constitutionally inadmissible conclusions ${ }^{63}$ and also in interpretations of constitutional law.

In a matter concerning the setting of transparent and pre-determined general rules for the assignment and reassignment of cases in the schedule of the common court's work, and thus, the right to a statutory judge, the CCC dealt with a situation where the composition of a panel of judges at a regional court had substantially changed during the proceedings. This had occurred in a specific case, and the changes were crucial because they pertained not only to the panel's composition (one

63 E.g. after the introduction of the 'solar tax' on profits from photovoltaic power plants. 
of its members was replaced) but also to the roles played by the panel members (presiding judge and judge-rapporteur). The problem was that the changes were made within a court department that had no binding mechanism for reassigning cases. The composition of the panel was completely at the discretion of the head of the department and was changed based on the head's sole decision. The CCC likened this situation to a case where changes would be made at a lower, but not smaller, court by the court's president. It concluded that such a procedure was prohibited for the entire court. It would be equally unconstitutional if the court's president could reassign cases themselves. Using the same logic, it would be absurd, according to the CCC, if such a power were vested in the head of a court department, although this was not explicitly prohibited by the law.

An ad absurdum argument was also used in proceedings concerning the right to equal treatment under Article 14 of the Convention (and the corresponding provisions of the Charter) and Art. 1 and Art. 10 (1) of the Charter. According to these provisions, '[a]ll people are free and equal in their dignity and in their rights' and '[e]veryone has the right to demand that [their] human dignity, personal honour, and good reputation be respected, and that [their] name be protected'. The CCC thus concluded that the relevant provision of the Registered Partnership Act was unconstitutional, because it would be illogical to prohibit any of the registered partners from becoming an adoptive parent. This was because the same law envisaged that registered partners could care for a child and even bound the other partner to protect and raise the child.

In a case concerning the right to privacy and self-determination in terms of information pursuant to Art. 10 (2) and (3) and Article 13 of the Charter, the CCC dealt with the possibilities of and limits to the collection and use of traffic and location data on telecommunication operations. ${ }^{64}$ The court noted that interference with privacy should be balanced in criminal proceedings by the duty to inform the persons concerned ex post facto that their data had been provided. However, this duty could not be applicable, ad absurdum, in the case of a missing person, as the person sought and found will learn that the police have been processing their data precisely when they are found. Consequently, this cannot constitute an excessive interference with the above-specified rights.

The CCC also used an ad absurdum argument in a case concerning its position in the structure of Czech institutions and the separation of powers. The case concerned a possible annulment of the provisions on a default judgement on the grounds of their variance with the principle of equality of the parties laid down in Art. 96 (1) of the Constitution, Art. 37 (3) of the Charter, Art. 6 (1) of the ECHR, and Article 14 of the International Covenant on Civil and Political Rights. However, the CCC inferred (or rather confirmed its earlier conclusion) that it should not annul legal regulations in cases where they can be interpreted in conformity with the Constitution. According to the CCC, the opposite approach would be absurd and unsustainable. It 
would amount to abandoning the principle of judicial self-restraint and would open the floodgates to the annulment of a wider range of legal regulations.

\subsubsection{Argumentum a contrario / arguments from silence}

This argument, too, only appears in several cases. It is used, for example, in the interpretation of Article 41 of the Charter, according to which the rights listed in that provision can only be claimed within the confines of the law. Article 38 of the Charter, concerning the right to a statutory judge, is not among them. Consequently, if this provision refers to a legal regulation, then it cannot be applied in that the right to a statutory judge is precisely defined by such a regulation. To the contrary, based on interpretation of Article 41 of the Charter, this provision can also be invoked beyond the scope of the laws implementing it. ${ }^{65}$

Within the set of decisions under scrutiny, an a contrario argument is also used in the interpretation of Art. 10 (3) of the Charter. This provision protects everyone against unauthorised collection, publication, or other misuse of personal data. The establishment of a 'negative register' of debtors (consumers) thus naturally interferes with this right. Nonetheless, the CCC concluded that from the wording of the cited provision a contrario, this right can be limited in an 'authorised' manner. This may refer to an individual interest of the sellers and the collective interest of society in preventing over-indebtedness of consumers. According to the CCC, a society-wide interest also includes an interest of the State, whose bodies are disproportionately burdened by efforts to deal with the already existing over-indebtedness. ${ }^{66}$

A special position in the current set of decisions belongs to a case of good-faith acquisition of the ownership title from a non-owner. In this case, the a contrario argument applies not with regard to constitutional law as such but rather with respect to the case law of the CCC that interprets it. At the same time, it is used as part of the judicial dialogue held between the CCC and the Supreme Court. The CCC deviated from the wording of the law (see above, for grammatical interpretation) in this case and inferred the possibility of acquiring the title from a non-owner if the acquiror does so in good faith. Nonetheless, the Supreme Court adhered to conservative interpretation based on the wording of the law and opinions prevailing among the professional public. It also noted, in an attempt to justify its decision, that the CCC had yet to formulate explicitly this option in its case law. The CCC countered by citing its previous case law and by pointing out that its interpretation was apparent based on the $a$ contrario argument. ${ }^{67}$

65 I. US $2769 / 15$.

66 Pl. US 10/17.

67 The given paragraph contains a passage that, in view of the way it is phrased, may also imply that although this was a decent dig at the Supreme Court, it was stingy. Indeed, the CCC noted, '[a]nd finally, even the Supreme Court's case law proves that the court understands the conclusions pronounced by the Constitutional Court in I. US 2219/12 of 17 April 2014'. 


\subsubsection{Argumentum a simili and, within it, analogy}

Arguments relying on analogy are also rare in the set under examination. Its importance should not be underestimated, nonetheless. It represents a useful tool that can be utilised effectively by Czech courts in general (i.e. not only by the CCC) to overcome gaps in Czech legislation resulting from poor work of the legislature. Indeed, using an assertive application of analogy, the courts have managed to ensure the performance of the country's external commitments, typically towards the EU and European Union law.

In the set of decisions under assessment, the CCC has used analogy to infer the State's duty to provide effective access to legal aid to detained foreigners in proceedings on administrative expulsion. It first notes that the necessary legislation is lacking at sub-constitutional level. It then goes on to analyse the background and principles it had inferred in its case law in relation to the right to legal aid in criminal proceedings for persons deprived of personal liberty. The Court then provides a thorough comparison of the respective situations of the two groups ${ }^{68}$ and states that they are comparable and the principles inferred thus also apply analogously to foreign nationals. ${ }^{69}$

The CCC's approach is not so diligent in its ruling concerning procedural succession and its limiting conception. Indeed, when defining the contents of the right of access to the court, the CCC follows, among other things, from its previous case law. In doing so, it notes that a specific ruling, to which it refers, could be used by analogy in the case at hand. However, unlike in that decision, the Court fails to lay out reasons that would explain and justify their analogous application. Nonetheless, this is not a genuine use of analogy as a method of interpretation. The said decisions are used as a supporting argument within a broader and unadmitted purposive interpretation of the right of access to the court, protected by Art. 36 (1) of the Charter.

Analogy is used in a very interesting manner in a decision concerning an amnesty granted by the President of the Republic and the subsequent review of whether or not the conditions under which the amnesty was announced are met. The CCC first notes that amnesty decisions are clearly issued in favour of the accused (the convict) and rendered by the executive branch. Later decisions issued within a review of the set conditions might already go against the accused. Therefore, the CCC considers it necessary to protect the procedural rights of the accused in this regard, and the

68 It concluded that '[b]oth groups of persons are deprived of personal liberty and the harm threatening a foreigner in case of his or her expulsion is comparable to or even greater than the harm threatening the accused in criminal proceedings. There is no practical difference between administrative expulsion and expulsion which can be imposed on a foreigner as punishment in criminal proceedings. Moreover, if a foreigner escaped from his or her country because he or she was at risk of death or torture or some other type of ill-treatment, then the harm he or she may suffer in case of expulsion to this country is greater than the harm threatening the accused in criminal proceedings'.

69 I. US 630/16. 
decisions should thus be made by the judiciary, rather than the executive branch. The CCC supports this conclusion by referring to an analogous solution in criminal law. Indeed, all decisions regarding a violation of the conditions pertaining to a sentence are made by the Czech judiciary, and not by the executive branch. ${ }^{70}$ This conclusion is logical at first glance. However, it neglects the fact that the use of analogy in criminal law has its limits. This limit was exceeded in the present case. By its decision, the CCC has inadmissibly established an entirely new decision-making power and, moreover, complemented sub-constitutional law. ${ }^{71}$

Analogy enables the CCC to overcome clear errors committed by the legislature. One such case is also included in our set of decisions. The Czech legislature has yet to adopt a law that would sufficiently regulate a Francovich-type liability in the Czech Republic. A problem lies in the fact that while this type of liability is enshrined directly in EU law, national law is supposed to set a number of individual conditions. These are not and cannot be laid down by EU law, in view of its limited scope. Regulation at both these levels is necessary to ensure satisfactory functioning of this legal institute. The Constitutional Court dealt with a similar issue in the past in relation to Czech law. Indeed, Art. 11 (4) of the Charter provides protection to the right of ownership against expropriation or forced restriction in public interest, but no follow-up provisions have been enacted. The CCC has inferred the need for an analogy with a regulation that would come the closest to this issue in terms of its contents and purpose-the Liability of the State Act. ${ }^{72}$ Regarding the Francovich-type liability, it inferred that these were similar situations with the same possible solution. Ultimately, the common courts had the duty to apply the Liability of the State Act even to matters not expressly listed in the Act. $^{73}$

The a simili argument is used only once within the set of decisions under scrutiny: in the case of provisions requiring job seekers to perform public service. In this case, the CCC adheres to international conventions that guarantee the right to reasonable security in unemployment. ${ }^{74}$ Unemployed persons could be divided into three categories, specifically a) persons unable to work; b) persons capable of working, but unwilling to do so; and c) persons capable and willing to work. Further, only the last group benefits from protection. The CCC notes that refusal to accept a suitable job is one of the 'distinguishing' features of unwillingness. The CCC then concludes a simili that refusal of a public service offer is a similar feature, conforming to the Constitution. The Court properly justified all this by comparing the features of an offer of suitable employment to an offer of public service.

70 Pl. US 36/17.

71 Five justices, including specialists in criminal law, expressed a dissenting opinion. Four of them explicitly opposed the application of the analogy in the way the Constitutional Court had done so in the case at hand.

72 Act No. 82/1998 Coll., on liability for the damage caused during the exercise of public authority by a decision or an incorrect official procedure.

73 IV. US 1521/10.

74 The Social Security (Minimum Standards) Convention and the European Code of Social Security. 


\subsubsection{Interpretation according to other logical maxims}

The set of decisions under examination also shows the effects of the principle of $u t$ res magis valeat quam pereat. It does not appear here under this designation. Instead, the CCC speaks on the effectiveness and efficiency of legislation. The Court notes in an asylum case that the right to effective judicial protection under Art. 36 (2) of the Charter envisages the possibility of claiming new facts, which the applicant may have failed, for justifiable reasons, to present in proceedings before an administrative authority. Without this option, the rejection of an application for international protection would not be effective. ${ }^{75}$ Similarly, it infers in another asylum case that the seven-day deadline for filing an application for international protection is insufficient if the foreigner lacks access to qualified legal aid during that period. No effective means of protection is available, either, if a foreigner is not sufficiently advised of the possible consequences throughout the EU of their failure to apply for protection. It follows from the above that the instruments for the protection of foreigners' rights must not be applied mechanically and automatically by Czech authorities, and that their actual impact must be considered. ${ }^{76}$ A line of interpretation of fundamental rights that ensures actual protection has to be preferred. In contrast, an approach that attains the formally pursued goals (i.e. everything seems to be in order in terms of purpose) but does not work in practice must be rejected. Finally, the above-cited decision concerning the duty to refer a question for a preliminary ruling in a situation that is or may be acte clair merits mention here. In this case, too, the CCC has inferred the generally correct procedure for referring questions for a preliminary ruling by the courts of last instance, while invoking the principle of effectiveness.

All the cases described above exhibit a minimalist approach to this principle. Consequently, exactly in line with its own position, the CCC does not require the maximum possible but only a minimum of what is necessary for the effective attainment of the purpose followed by the relevant legislation. ${ }^{77}$

\subsection{Domestic systemic arguments}

\subsubsection{Contextual interpretation in a narrow and broad sense (including the so-called 'derogatory formulae')}

Contextual interpretation is usual in cases where the CCC infers a certain conclusion on the basis of a combination of several provisions of the Constitution and the Charter. This is typical of Art. 1 (2) of the Constitution, according to which the Czech Republic is to observe its obligations arising from international law. This provision is often used in combination with other provisions, especially of the Charter. 
This is how interpretation is found that conforms either to international treaties binding on the Czech Republic or to decisions of international courts. However, this is not a matter of direct determination of the contents of one provision on the basis of another. The logic is that the second provision opens the door for reflecting an external source (typically a European convention), which in turn influences the interpretation of the first provision. As regards the interpretation of fundamental rights and freedoms and the determination of their meaning, the contextual interpretation is a common method used by the CCC, observed in 12 decisions (including one occurrence of 'derogatory formulae').

A specific instance that is not in the current set of 30 cases is a decision on consumer protection. ${ }^{78}$ This case is so unique that it has to be mentioned at least obiter dictum in this research. Consumer protection is not directly enshrined in the Czech Charter. In EU law, it is safeguarded by Article 38 of the EU Charter. This article states merely that 'Union policies shall ensure a high level of consumer protection'. All the relevant legislation is provided by secondary law. In the mentioned ruling, the CCC states that a common court has to ensure a party's right to judicial protection under Art. 36 (1) of the Charter; in doing so, it has to proceed in conformity with Art. 1 (2) (respect for international obligations) in conjunction with Article 10a (possibility of transferring the exercise of certain powers to an international organisation) and Article 4 of the Constitution (fundamental rights and basic freedoms enjoy the protection of judicial bodies). Based on these provisions contained in the Czech Constitution and the Charter, the CCC infers its duty to promote Article 38 of the EU Charter and thus protect consumers, or else it would violate the relevant provisions of the Constitution and the Charter. However, it ultimately makes its decisions in the way prescribed by secondary EU law, because the EU Charter itself does not provide any guidance. Secondary EU law is subsequently reflected in the law protected by the Constitution and the Charter. This procedure is not necessary from the viewpoint of EU law and is, in fact, not required by it. It does not correspond to the principles of application of EU law as formulated by the ECJ, and is 'activist' in the light of these principles. This approach is also problematic in terms of Czech law and, above all, overly complicated. It is basically like scratching behind an ear with the wrong hand, because the EU Charter is binding in itself; nonetheless, the Constitutional Court would have to leave its comfort zone and change its view of the EU law as it did with regard to international law in its bankruptcy judgement. ${ }^{79}$ It may somewhat excessive to infer, based on the right to a fair trial, that the consumer may withdraw from a distance agreement within a period of one year, and also that the consumer is not liable for a reduced value of goods, even if they handled such goods in a way other than necessary for becoming acquainted with the goods. 
As regards contextual interpretation in a narrow sense, this concept is observed in two cases concerning determination of the significance of a fundamental right protected by the Charter. The Charter envisages that its provisions will be further specified by statutory law in some cases, although the same is not anticipated in other instances. Furthermore, Article 41 of the Charter sets out which rights can only be asserted within the limits of laws adopted for their implementation. The CCC takes advantage of this in its interpretation of other rights not affected by this article. The Court thus obtains an argument that provides room for broader interpretation and also broader application of the relevant fundamental right. It is not limited by statutory law, even if such a law has been enacted and its enactment is envisaged by the Charter. Meanwhile, the current set of decisions does not include a case in which a fundamental right would be interpreted purely in view of its position in the structure of the Charter.

An illustrative example of contextual interpretation in a broad sense is a case where the CCC states that, unlike Art. 10 (2) of the Convention, Art. 17 of the Charter does not contain any explicit reference to obligations and responsibility (or liability). However, the Constitutional Court subsequently infers them from the Constitution itself and its provisions. Using a similar logic, the CCC further states that the number of legitimate objectives for restricting the freedom of expression in Art. 17 (4) of the Charter is smaller than in the case of Art. 10 (2) of the Convention. In contrast to its equivalent in the Convention, Art. 17 (4) of the Charter does not contain an explicit option of limiting the freedom of expression with a view to protecting impartiality and authority of the judicial branch. However, this has not given concern to the CCC because, according to its interpretation, these values are protected within protection of the rule of law under Art. 1 (1) of the Constitution. According to the CCC, they may serve as a legitimate objective for restricting the freedom of expression, as impartiality of the judicial branch is protected at the constitutional level through the right to an impartial court and by the Constitution as such, according to which no one may jeopardise the impartiality of judges. ${ }^{80}$

As regards derogatory formulae, the present research has not found any of the principles of lex superior derogat legi inferiori, lex specialis derogat legi generali, and lex posterior derogat legi priori in the set of decisions under scrutiny. They are relevant, however, in the context of the decision on home births, which has already been mentioned. In this ruling, the CCC quotes its earlier case law and points out the influence of international standards of human rights protection in Czech law. Interpretation cannot be used to reduce the level of protection of fundamental rights and freedoms that have already been achieved in Czech law, even if this occurs on the basis of international treaties (and the way they are interpreted by international courts). ${ }^{81}$ This limits the potential scope of derogatory formulae in Czech constitutional law. 


\subsubsection{Interpretation of constitutional norms per domestic statutory law (statutes, decrees)}

The CCC is not bound by sub-constitutional law and is therefore not part of its reference framework. It further applies in interpretation of the Charter that the notions and concepts used in the Charter have autonomous contents. Their contents are therefore relatively independent of sub-constitutional law and its potential change need not affect them in any way. ${ }^{82}$ The current set of decisions includes cases where the text of sub-constitutional law serves as an argument for some specific interpretation of the Constitution, as well as a case where the CCC has ignored the wording of sub-constitutional law altogether, even in a situation where the Charter explicitly refers to conditions laid down by the law. ${ }^{83}$ That is, the CCC should have adhered to its wording, given that the CCC is primarily a value- and policy-oriented body rather than a classical tribunal. The CCC and its justices thus work in a value-laden environment, and if sub-constitutional law fits into this context, it is reflected. Otherwise, reasons are sought and highlighted on the exclusion of sub-constitutional law.

When determining the meaning of notions used by the Charter, the CCC is willing to follow their meaning defined in ordinary law and even interpret them based on the explanatory memorandum to a statute. However, this is not very frequent. This method is deployed in three cases in total, in two of which the CCC fully accepts statutory law for the purposes of interpreting a fundamental right; in one case, it does not.

A situation where the CCC takes sub-constitutional law into account and fully accept it for the purposes of interpreting a fundamental right is the case concerning kindergartens and the question of whether schools could refuse a child who had not been properly vaccinated or had no proof of immunity against infection, or could not undergo vaccination owing to permanent contraindications. In this case, the CCC interprets Article 33 of the Charter, which lays down that '[e]veryone has the right to education'. However, it remains silent on the scope of this education and what levels of the educational system are covered by this very concept. This is, nonetheless, specified in the Schools Act. The CCC notes that the latter Act is one of the laws implementing this provision of the Charter and, therefore, adopts the definition contained in that Act. ${ }^{84}$

Meanwhile, the CCC's decision concerning the possibility of acquiring the ownership title from a non-owner ${ }^{85}$ shows little willingness to follow the text of subconstitutional law. The right of ownership is protected by Article 11 of the Charter, but only in general. Specific protection is ensured at the level of statutory law. Until

$82 \mathrm{Pl}$. US $1 / 12$.

83 The Charter uses two approaches: some rights are complemented through statutory law (for example the Art. 7 of the Charter states that "The inviolability of the person and of her privacy is guaranteed. They may be limited only in cases provided for by law") while the same is excluded in other cases. The CCC's procedure in interpreting and applying rights falling within one group or the other should not be the same. Indeed, the space for review is substantially broader in the latter case.

84 Pl. US 16/14.

85 I. US $2219 / 12$. 
the 2012 recodification of Czech private law, it was not possible to acquire the ownership title from any person other than the owner. In contrast, the new law protects the new owner's good faith and thus permits this option in specific cases. In a case that was heard after the adoption of the new legislation, but still during the effect of the former regulation (which thus should have been applied), the CCC granted the level of protection afforded by the new regulation. ${ }^{86}$ More accurately, the Court used it as an argument to support its concept of protection of the new owner's right of ownership. It did so despite the fact that the wording of the law (which governed the relevant legal relationship) had not changed and did not allow this, and that the Charter itself had not been changed either. Indeed, the Charter expressly referred to the statutory concept of the right of ownership. The exceptional nature of the situation is illustrated by the fact that this approach was opposed by a substantial section of the professional public as well as the Supreme Court. The CCC conducted an extensive judicial dialogue with the Supreme Court regarding acquisition of the title from a non-owner. Indeed, both these courts relatively vigorously opposed each other and were unable to find a common approach.

The CCC's approach of the wording of statutory law is likewise rather dubious, as well as that of the Charter in its decision concerning a hotel manager who had required Russian guests to sign a declaration condemning the conduct of their own country with regard to the annexation of Crimea. ${ }^{87}$ In this ruling, the CCC addressed the prohibitions of discrimination enshrined in the Charter and in the Anti-Discrimination Act, which differ from each other. The Anti-Discrimination Act provides an exhaustive list of prohibited grounds. The CCC construed the Charter in the same way, although the list contained therein comprises not only a prohibition of discrimination on explicitly stated grounds but also a discrimination category based on 'another position'. This category makes it possible to apply further grounds unknown to the Charter. Consequently, if the CCC denied this 'invitation', it interpreted the provision with surprising restraint. This is not typical of the way it tends to interpret the Charter. Thus, rather than a methodologically correct interpretation process, this amounted to what could be described as 'situational interpretation' of the Charter. Although we can assume that a case will be decided in a certain way, we know that the same provision would be construed differently if the facts were different (not involving Russia, but some other country).

\subsubsection{Interpretation of the Constitution per the case law of the Constitutional Court}

This method of interpretation is very common and represents the basic modus operandi of the CCC. Basically all the rulings of the CCC include references to its previous case law. At the same time, a snowball effect is apparent in the CCC's decisionmaking. The conclusions of its previous decisions are repeated in new decisions,

86 Ibid.

87 II. US 3212/18. 
which are added to the original ones and then quoted together. This ultimately creates the impression of a clearly and convincingly established law. Therefore, judgements of the CCC, strongly resembling the ECJ, lack any detailed analysis of facts in relation to the rule on the basis of which the decision is made. In substance, the CCC merely constantly repeats its general conclusions until it creates the impression of a precedent. ${ }^{88}$ How could the interpretation be different if it has been confirmed so many times? The benefits of this approach are generally known and undisputed. Moreover, similar courts, especially the ECtHR and ECJ, operate in a similar way. Nonetheless, the approach gives the impression that the CCC occasionally steps on the very boundary of what is appropriate. The way it works with its previous decisions implies that it perceives them as precedents (although it has never stated this openly), which they are not. At the same time, it uses an authoritative and paternalist style, similar to a parent who does not explain a problem and simply dismisses their child's question by saying 'because I said so'. This creates the impression that the first and foremost imperative for the CCC is not the Constitution, and the constitutional and ordinary legislators' ideas enshrined in it, but rather its own ideas of how things should operate. The wording of the law and the manner in which it is interpreted are hidden under a load of case law. The Constitution and the Charter then serve merely as some sort of background scenery devoid of substantial meaning.

\subsubsection{Interpretation of the Constitution per the case law of common courts}

The approach to the case law of common courts is based on the CCC's position and also the way the latter perceives its position. The CCC has repeatedly emphasised that it is not a part of the system of common courts. It refuses to act as another court of instance and to apply 'simple law'. The CCC quotes decisions of lower courts for three principal reasons. First, it does so to illustrate the overall situation and better clarify the facts of a case. Second, the CCC works with them in cases where it conducts a judicial dialogue with common courts and opposes their conclusions. Third, and this happened only in several cases in the current set, the CCC used decisions of common courts as supporting argument for the conclusions it reached itself. Thus, the CCC clearly expects common courts to be loyal to it and follow its interpretation, which is understandable. Meanwhile, even the mentioned rare cases prove that the CCC is capable of recognising the authority of the two supreme courts, in the set of cases under assessment, this was true only when the CCC was

88 The CCC is generally not allowed to depart from its previous decision, as made possible after the adoption of Plenum's opinion (stanovisko). In this respect, its decisions resemble precedents. However, they are not precedents in a way that this term is understood in common law, since they do not constitute new general rules of law. They merely interpret existing rules, created by the rule-maker, for specific cases. The CCC requires that the same protection be granted in factually similar cases. The crux of the problem, however, is that facts are often not dealt with in the sophisticated way that the common law courts do in subsequent cases. Instead, the so-called 'legal sentences' gain importance. As a result, the individual context of each case loses its importance. 
interpreting 'simple law'. Since common courts generally do not rule directly on the basis of the Constitution and therefore do not routinely interpret it, their decisions cannot form a common basis for the CCC's decisions. Despite this fact, the CCC refers to individual court decisions in three cases to strengthen and support its own conclusions.

\subsubsection{Interpretation of constitutional provisions and fundamental rights based on normative acts of other domestic state organs}

The present analysis found no decision in the set under scrutiny that could be directly subsumed under this point, as defined in the research design. Nonetheless, the influence of other governmental authorities on the CCC's decision-making is beyond dispute. Indeed, in matters related to the annulment of a statute or some other regulation, the Constitutional Court Act envisages that these authorities could intervene in the proceedings before the CCC. The CCC has thus requested an amicus curiae brief from the Chamber of Deputies and the Senate of the Parliament of the Czech Republic, as well as from the Government and the Public Defender of Rights. The conclusions presented by these bodies are then used subsidiarily in the interpretation and substantiation of the CCC's conclusions. The CCC has also considered an opinion of the Committee for Human Rights and Biomedicine of the Czech Government Council for Human Rights. ${ }^{89}$ A common practice is that the justice-rapporteur requests an opinion from individuals and institutions that can significantly contribute to the resolution of the problem at hand, although in some cases, their choice may be arbitrary.

\subsection{External systemic and comparative law arguments}

\subsubsection{Interpretation of fundamental rights on the basis of international treaties}

This section outlines the position of international treaties in the system of Czech law and the CCC's approach to them. In its 'bankruptcy judgement' ${ }^{90}$ the CCC states that, in view of Art. 1 (2) of the Constitution, international treaties form a part of the constitutional order even if they are not included in the exhaustive list given in Section 112 (1) of the Constitution, which defines the constitutional order. Decisions are thus commonly made based on not only the Charter but also international treaties protecting fundamental rights.

What is noteworthy, however, is the way the CCC works with the text of international treaties in general and with the wording of the European Convention in particular. Only in a single decision in the set of cases under scrutiny is its international 
origin considered and the impact of this fact on its interpretation emphasised. ${ }^{91}$ In this specific case, the interpretation concerns the concept of 'property'. In its ruling, the CCC states that this term is subject to 'autonomous interpretation, i.e. interpretation independent of any potential definition of the concept in national legislation, and moreover, to relatively broad interpretation'. This aspect is not emphasised in any other decision. To the contrary, the Czech Charter and the rights it protects are interpreted in the context of the European Convention and other international treatiesmore visibly and more apparently so in the case of the European Convention.

In this regard, the 'principle of homogeneity' can be considered to have become a part of Czech constitutional law as a result of the CCC's decisions. Indeed, the CCC interprets the same rights protected by the Charter and the Convention in the same way. If there is a difference in the wording of a right enshrined in the Charter and the same right protected by the European Convention, the difference tends to be neglected (not highlighted) and the right is still interpreted homogeneously, according to the European Convention. ${ }^{92}$ The CCC itself has never designated this approach as such.

The situation described is somewhat paradoxical. The Convention and other international treaties should be subject to autonomous interpretation and be independent of Czech law. Moreover, public international law itself sets the methods of its interpretation. Meanwhile, the Charter, as part of the Czech Constitution, should be interpreted using a methodology inherent to and in the context of Czech law. There might be overlaps and areas of the same meaning, as well as cases where one and the other can be interpreted differently. Nonetheless, the influence of international treaties, including the Convention, has completely prevailed, and the CCC clearly has no interest in interpreting the Charter in a different way.

It must be emphasised at the same time that, in fact, the CCC does not provide interpretation of the Convention. Its contents are determined through ECtHR case law. Consequently, if the CCC's work were to be evaluated only on the basis of the 30 selected decisions, it could be stated that this party to the Convention (i.e. the Czech Republic) has given up on interpreting the Convention itself using the rules of public international law.

The approach to EU law (and the EU Charter) differs from the one taken to the Convention. Moreover, the conclusions described above concern situations involving parallel regulation of a certain right in Czech and international law. A specific instance (not included in the set of 30 cases) is the previously analysed decision on consumer protection, ${ }^{93}$ which is not directly afforded by the Czech Charter. There is no regulation parallel to the external regulation. However, consumer protection is part

91 Article 1 of the Protocol to the Convention for the Protection of Human Rights and Fundamental Freedoms

92 This is clearly demonstrated by the interpretation provided in previously analysed ruling I. US $2617 / 15$.

93 II. US 2778/19. 
of EU law, specifically Article 38 of the EU Charter, and is put into practice through secondary law. While the CCC professes Article 38 of the EU Charter in its 'activist' decision, it applies secondary EU law and, on its basis, creates the standard for consumer protection in Czech law. ${ }^{94}$ It is paradoxical that, in this specific case, a fundamental right is elaborated not against the backdrop of an international treaty as such but rather based on a regulation (directive) adopted on the basis of the treaty.

Subsidiarily and, in fact, without any link to the solution adopted in the case, the ruling further states (while recalling prior case law of the CCC) that, according to the CCC, the EU Charter is considered a part of the reference framework for review and a criterion for review, and Czech law emphasises the need to also approach interpretation of the law from the viewpoint of the EU Charter. ${ }^{95}$ However, the position of the Charter is not so clear. The only certainty on the basis of the CCC's case law is that EU law as a whole is not a part of the reference framework for review (abstract or specific) of national law. ${ }^{96}$

A greater or lower willingness to take the EU Charter, as a highly specific source of EU law, into consideration can be found in the individual decisions of the CCC. This can be demonstrated in the interpretation of the right to protection of privacy under Article 10 of the Charter. Unlike the provisions enshrined in Article 8 of the EU Charter, the right to protection of privacy cannot be limited 'on some other legitimate basis laid down by law'; the CCC resolved this problem by using an interpretation conforming to this provision. It did so, however, in a situation where it could and should have applied the EU Charter directly in terms of EU law. ${ }^{97}$ This is a recent decision, which thus reflects the continuing disjointed approach of the CCC to EU law and to the EU Charter.

The differences in the CCC's approach to the European Convention and the EU Charter are understandable. The Convention has an exceptional position among the sources of law used by the CCC; the EU Charter cannot match it in this regard. Indeed, its scope is limited based on the rule 'if [the] EU law applies, the Charter applies', which the CCC has embraced. ${ }^{98}$ There is no similar limitation laid down in the Convention. The CCC thus treats it as a general instrument for interpreting the Charter. Furthermore, the CCC does not avoid further international or supranational sources either. The set of decisions examined includes rulings where the CCC accounts for the Convention on Human Rights and Biomedicine, ${ }^{99}$ the Social Security (Minimum Standards) Convention and the European Code of Social Security, the Convention Concerning Forced or Compulsory Labour, ${ }^{100}$ the Convention on Cybercrime, ${ }^{101}$ the

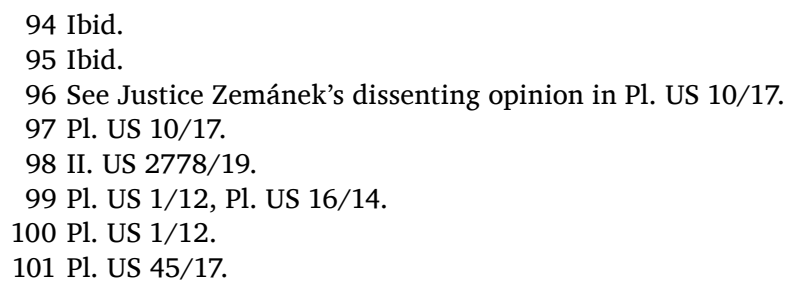


International Covenant on Civil and Political Rights, ${ }^{102}$ and the Convention on the Rights of the Child. ${ }^{103}$

\subsubsection{Interpretation of fundamental rights per individual case decisions or case law ('judicial' practice) of international fora}

The present analysis found no decision that would be issued by another international court (other than ECtHR or ECJ, to be precise), save for one. This was the decision of the International Court of Justice regarding jurisdictional immunity (Germany v. Italy) dated 3 March 2012. It might be said somewhat poetically that no stars can be seen when the sun is shining. In the case of the CCC, the sun is the ECtHR. No debate whatsoever is pursued in the decisions being examined as to the nature of ECtHR's decisions, with the sole exception of dissenting opinions. This question has clearly been de facto resolved. What differs is the rhetoric that the CCC uses when approaching decisions of the ECtHR. Several basic approaches can be distinguished in this regard: first, the CCC mostly formulates its own opinion and refers to ECtHR case law in support of its arguments. It then uses the phrase 'the CCC, in conformity with...' or 'the CCC agrees with...' Second, the CCC adopts a parallel approach, where it both interprets the Charter and repeats the conclusions following from ECtHR case law. The third approach could be described as borrowing or substitution, as seen in the citing of ECtHR case law without simultaneously considering Czech law, which is assumed to be the same. ${ }^{104}$

The CCC's approach to the Charter and the Convention, as interpreted by the ECtHR, can be likened to the DNA's double helix. DNA carries genetic information, which consists of two mutually intertwined strands. Similarly, the CCC defines the contents of fundamental rights based on the Charter and the Convention, both of which carry one piece of information as to the desired standard of protection in the Czech Republic. In some of the rulings, ECtHR judgements are also de facto treated in this manner. They intertwine with the Czech legislation and decisions of the CCC and form a single whole.

The position of ECtHR case law is fully-fledged and comparable to prior case law of the CCC. In this respect, it is incomparable with the decisions of common courts. ECtHR case law is not questioned; rather, it is adopted without further considerations. What is characteristic of these cases, however, is the limited attention paid to the facts of the cases dealt with by the ECtHR; this can lead to conflicts of opinions among the individual justices, which are, in turn, reflected in dissenting opinions. The subsidiary nature of the ECtHR's work is overlooked, as is the fact that its decisions lack effects erga omnes.

102 Pl. US 49/10.

103 I. US 3226/16.

104 For general examples, see Petrov, 2019, p. 175. 
The described approach is practical. The CCC, as a young tribunal lacking its own history (and mythology), thus basically borrows another's mythology. Meanwhile, the tribunal supports its own authority, because a conclusion made by the ECtHR must inherently be correct.

The CCC's approach to the ECJ is different. On the one hand, the CCC acknowledges the ECJ's authority to interpret EU law, and thus also the EU Charter. On the other hand, the CCC is effective in circumventing it. ${ }^{105}$ It emphasises that what it interprets is not EU law (which is up to the ECJ) but rather the Czech Constitution. ${ }^{106}$ The CCC makes this abundantly clear as it provides different interpretations regarding the duty to refer questions for a preliminary ruling and also as regards the question of possible discrimination in a well-known case concerning Czechoslovak pensions, as the first constitutional tribunal in the EU to rule at variance with a prior decision of the ECJ. ${ }^{107}$

\subsubsection{Comparative law arguments}

Comparative interpretation is a frequent method of interpreting the CCC's case law. ${ }^{108} \mathrm{~A}$ comparison or at least a reference to a foreign legislation or decision is present in 15 cases, which is a truly high number, exceeding any other methods of interpretation analysed thus far. This is also why the individual cases will not be described in any further detail. It must be emphasised, however, that comparative arguments, as used by the CCC, have nothing to do with comparison as a scientific method. These are two completely different categories. Indeed, comparison as carried out by the CCC never goes beyond a mere statement-the situation in another country is such and such, similar/the same as here. It is superficial, subject to two exceptions, ${ }^{109}$ which are nevertheless limited to conceptual comparison (in the best case).

A characteristic of comparative interpretation is that it is not the crucial method. It does not form the axis of any given decision; it aims merely to support and emphasise the conclusions reached by the CCC in some other way. Moreover, none of the relevant decisions handles foreign law directly. Its contents are ascertained either from professional comparative literature ${ }^{110}$ and via decisions rendered by foreign courts.

105 Hamulák, 2011, pp. 288-308.

106 Sehnálek and Stehlík, 2019, p. 186.

107 See also Hamulák, 2014, pp. 103-112.

108 This is true in general; see ibid., p. 96.

109 This was true of ruling Pl. US 7/15, where the CCC examined the Austrian law and decision of the Austrian Constitutional Court File No. G 119-120/2004. The CCC's decision III. ÚS 3457/14 is relatively close to the contents of foreign legislation. In that decision, the CCC noted a similarity of substantial features and thus inferred that the conclusions made by the BVerfGE could be transferred to the Czech legal environment. What helped in this regard was that the BVerfGE followed from the ECtHR's case law.

110 I. US 425/16 - using a general reference to other laws via UNHCR, March 2010, p. 467; further, in $I$. US 1434/17, a comparative view of the question of the State's liability for damage was mediated by Van Damm, 2013, p. 537. 
The comparison or references to foreign laws or decisions are typically concerned with Germany and Austria. This is understandable as the Czech Republic shares legal history with these countries. They also benefit from an uninterrupted legal tradition and the ensuing robust jurisprudence, as well as the conceptual wealth of their case law. A comparison with Slovakia is used only twice, ${ }^{111}$ which is surprising in view of the long shared history and similarity in legal thought.

The objects of comparison are not limited only to the laws of other countries. In one case, the CCC has referred to the fact that the principles of legal certainty and protection of legitimate expectations also comprise EU law. ${ }^{112} \mathrm{EU}$ law is also taken into account in the interpretation of the institution of liability of the State for damage, where the CCC referred to the concept of this institution in the case law of the ECJ (Francovich). However, such an approach is rather paradoxical, leading to a circular definition, as it was the ECJ that inferred the concept of Francovich-type liability based on the very provisions governing liability of the State for damage in EU Member States.

In one case, the comparison is hinted at but not actually carried out because this was an argument used by a party to the proceedings. However, the CCC used it for a different purpose, noting that 'while the German, Austrian or First-Republic Czechoslovak concepts of judgement by default might be more suitable de lege ferenda, this does not imply that the current Czech concept [...] does not follow a legitimate public interest and is unconstitutional. ${ }^{113}$ This, too, indicates the limits of comparison and also that the CCC is well aware of them.

\subsubsection{Other external sources of interpretation}

The well of information and arguments for CCC decision-making is truly rich and includes a number of external sources. The CCC has applied an analysis ${ }^{114}$ carried out by the Office of the United Nations High Commissioner for Refugees (UNHCR). ${ }^{115}$ It has also referred to the following: Parliamentary Assembly Recommendation 1317 (1997) on vaccination in Europe; Guidelines on the Role of Prosecutors; a statement of the UN Human Rights Committee, Communication $\mathrm{N}^{\circ} 521 / 1992$, Vladimir Kulomin v. Hungary, UN document CCPR/C/56/D/521/1992; ${ }^{116}$ the report of the Venice Commission on the European Standards as Regards the Independence of the Judicial System: Part II - The Prosecution Service, adopted on 17-18 December 2010, Study No. 494/2008; ${ }^{117}$ the decision of the Council of Europe's Committee of Ministers: Twenty Guidelines on Forced Return of 4 May 2005; and the resolution of the UN

$111 \mathrm{Pl}$. US 10/17 and I. US 2769/15.

112 I. US 1434/17.

113 Pl. US 49/10.

114 UNHCR, March 2010.

115 I. US 425/16.

$116 \mathrm{Pl}$. US $17 / 10$.

117 Ibid. 
General Assembly titled 'Territorial integrity of Ukraine' of 27 March 2014, referring to the declaration of the Ministry of Foreign Affairs on the 5th anniversary of the illegal annexation of Crimea of 16 March 2019;118 and finally, General comment No. 14 (2013) on the right of the child to have their best interests taken as a primary consideration by the Committee on the Rights of the Children. ${ }^{19}$ These sources, too, play a supporting role and serve primarily to reinforce and increase the persuasiveness and clarity of the CCC's arguments.

\subsection{Teleological/objective teleological interpretation}

Teleological interpretation is an important method used by the CCC. However, similar to linguistic interpretation, it is only rarely expressly admitted. The CCC observes the purpose of the Charter and the Constitution, and this is true of all the decisions chosen. The opposite would be surprising, as the CCC itself has called on the common courts to move away from formalism associated with predominant use of linguistic interpretation. However, the set of decisions under scrutiny contains none where the CCC would use this method of interpretation openly, clearly, and systematically. Its use can be inferred, as this method has been deployed in seven cases. This conclusion might be unexpected. Indeed, one would expect more frequent and direct use of this method of interpretation. However, it can be explained by the choice of selected decisions. In particular, these were supposed to be recent decisions, and reflecting on the case law of the ECJ or the ECtHR. These preferences could have had a significant impact in this regard. The problem is that the CCC may refer to its previous case law and work with it, and thus need not revisit what has already been resolved. Moreover, it has passively referred to extensive case law of the ECtHR wherever possible. Consequently, the need for any deeper teleological analysis of the individual rights is substantially reduced. In contrast, the purpose is often considered in cases where sub-constitutional law is being interpreted. It is also taken into account in the tests of rationality and proportionality.

\subsection{Historical/subjective teleological interpretation (based on the intention of the constitution-maker)}

This method of interpretation is likewise not present in the selected decisions at the level of the Constitution (other than sub-constitutional law), even though the CCC has had the opportunity to use it. Historical interpretation suggests itself in the amnesty ruling analysed above, as the legislation in question has its origins in the Czechoslovak 'First Republic', from which the current Czech Constitution found inspiration, but this stone was eventually left unturned. ${ }^{120}$ The CCC came closest to 
historical interpretation when it referred to the case law of its Czechoslovak predecessor, but this was not an instance of genuine use of this interpretation method. ${ }^{121}$

\subsection{Arguments based on jurisprudence/scholarly works}

The circle of Czech constitutional lawyers is relatively small and its members tend to know one another very well, as they often work together both at the Constitutional Court and at law schools. This is true of both justices and their assistants. It is by no means exceptional if a Constitutional Court's justice also has part time jobs at a couple of law faculties. This has several consequences. It can be stated in general that the relationships in the circle of persons dealing with constitutional law (and EU law) appear harmonious to people outside the community, following the spirit of co-operation and mutual understanding. Where critical voices are raised, this usually concerns situations where the question dealt with by the CCC is highly sensitive in nature (meaning that the CCC is forced to create the State's policy in its ruling, such as in the cases of home births, e-sales, and homosexuals) or situations where the Constitutional Court shows empathy in its decision-making ('listens to the stories of individual people') but fails to reflect on the consequences this approach might have in everyday life and functioning of sub-constitutional law. Close interconnection with the academia often prevents any meaningful criticism in the field of constitutional law; such a criticism is actually quite uncommon. The law is first 'made' through the CCC's decision-making, and then taught by those who de facto made the law in their decisions, and the same people reflect on it in the professional literature they publish. This literature then influences the functioning of the CCC and serves as an argument on certain decisions. The academia can hardly play its role of supervisor of the CCC.

Professional publications are often used in the CCC's case law. One half (15) of the cases examined included a reference to some professional publication; the numbers would be higher if the analysis accounts for literature pertaining to subconstitutional law. In the vast majority of cases, the Court works with Czech literature, but a total of five decisions reference foreign sources as well. Surprisingly, German and Austrian commentaries are not used to a greater degree. Indeed, this would make sense in view of the CCC's willingness to use the comparative method. What is even more striking is that foreign literature dealing with the Convention is not used to an extent comparable to Czech literature. This would make perfect sense in a situation where the CCC works with the Charter as a fully comparable document. Indeed, it does refer to Czech commentaries regarding the interpretation of the Charter. This brings us to a relatively significant problem in the work of the CCC. Its decisions often refer to publications co-authored by one of its justices. This is quite understandable, on the one hand, as these people understand their work and it makes sense if they subsequently write a commentary or professional article. There 
is a rationale behind reflecting on such a publication. These works also undergo peer review and are published in high-impact magazines, which guarantees their quality. It can also be argued that they are often mere members of a collective of authors and have no influence over the other co-authors. This method of work is not good in systemic terms. It artificially creates the authority of the CCC's decisions. Although this institution needs no such support, it has taken advantage of it in more than a quarter of the cases in the set under scrutiny. A case where the justice-rapporteur refers to their own publication is then clearly wrong. ${ }^{122}$

\subsection{Interpretation in light of general legal principles}

General principles of law represent 'imaginary spice' in the CCC's case law, which is also illustrated by the frequency with which they are used. Their advantage lies in the fact that they are amorphous. Their contents are not precisely defined; the decisions do not actually work with their contents, but we still generally (even if vaguely) know what the CCC is trying to communicate. The principles that are (at times even repeatedly) referred to in our set of decisions include the following: legal certainty, predictability, and proportionality; equality; protection of the citizen's confidence in the law; the new owner's good faith; maintaining confidence of individuals in acts of a public authority; protection of acquired rights; predictability of judicial decisionmaking; ne bis in idem; and prohibition of retroactivity.

\subsection{Substantive interpretation/non-legal arguments}

The CCC does not avoid non-legal arguments in its decisions, although they are not that frequent (five decisions in the current set). Such an argument is especially apparent in the ruling concerning a hotel manager in Ostrava who required his Russian guests to sign a declaration concerning Crimea. ${ }^{123}$ This decision has been mentioned above. It consists of two very specific arguments. The first is factual and quite problematic. Indeed, the CCC pronounced the described step as lawful because the same service had been available elsewhere in the city (i.e. it was substitutable). The question, however, is how the CCC would assess the given situation if it involved a small town where a Russian guest would have no such alternative. In the same ruling, the CCC relied on a book written by Karel Čapek and a decision made by one of his characters. The fact that this was a reaction to a ruling previously made by the Supreme Administrative Court, which had cited a different Czech author, further reinforces the human touch in the Court's decision-making. While such a procedure is certainly conceivable as a way to spice up and humanise a decision made by the CCC, it is questionable whether it is really suitable and necessary in terms of its

122 In one case, the cited material was still in print and yet to be published, which is downright ridiculous, Pl. S 26/11.

123 II. US $3212 / 18$. 
form. From this point of view, dissenting opinions are clearly an unproblematic place where a justice can better express their personality. This often happens and justices like to use this option.

In one of its decisions, the CCC made a certain conclusion because this was fair ${ }^{124}$ and, in respect of the principle of data retention, it sought the 'lesser evil'; in another decision, in contrast, it highlighted the importance of good morals. ${ }^{125}$ In the latter case, the CCC even expressly admitted the possibility of deviating from the results of legal interpretation and also from the wording of the law. The result is that the CCC asks the judge to decide praeter legem and even contra legem.

\section{Reality of interpretation of law by ECtHR and ECJ}

Most (26) of the decisions that are of interest are issued by the ECtHR. The $27^{\text {th }}$ decision of this court was cited only indirectly through the scientific literature, without being specified. As such, it was not included in the research. Given the way the CCC approaches EU law, the influence of ECJ's case law in the field of human rights is negligible. Nonetheless, decisions of this court were part of the research. Out of three ECJ decisions to which the CCC referred, only one was dealing with fundamental rights, which are codified by the EU Charter.

The choice of decisions for examination followed the project's conditions. The task was to select those rulings that were used by the CCC in its decisions examined previously in section 3. of the present analysis.. The CCC quite regularly referred to several ECtHR rulings at once. Therefore, when choosing among several options, the present analysis preferred those decisions that concerned directly the Czech Republic or some other country included in the survey. Furthermore, priority was given to rulings that were cited repeatedly or where the context indicated that they could have a significant impact on the CCC's decision-making.

One interesting fact is that the decisions in this group pertained, in principle, to the same problems as those dealt with by the CCC. Nonetheless, the style of work at the ECtHR (and also the ECJ) clearly differed from the way the CCC operates.

\subsection{Grammatical (textual) interpretation}

As regards the individual methods of interpretation used by the three courts, grammatical (textual) interpretation serves them as the initial, basic method. This approach to interpretation is taken in most of the decisions of the ECtHR. The interpretation of the Convention based on an ordinary meaning of words is not used very 
frequently (only in three cases). In contrast, legal professional (dogmatic) interpretation is used much more frequently (in 25 cases). In three cases, the ECtHR took the advantage of interpretation based on legal principles.

While not sufficiently robust for deciding on the cases without exploiting other methods, textual interpretation did serve as the foundation on which interpretation could be built using other approaches. The importance of grammatical interpretation is substantially diminished because the ECtHR perceives the Convention as a 'living instrument'. Therefore, emphasis on its interpretation is not placed primarily (and only) on the actual text of the Convention but rather on the current social context of its functioning. Nonetheless, the text limits evolutive interpretation of the Convention and cannot be neglected. The ECJ refers to text of the EU Charter in its decisions.

As noted previously, the CCC is aware of the need for an autonomous interpretation of the Convention. In three cases, the ECtHR indeed expressly provides such autonomous interpretation of notions used in the Convention. The absence of emphasis on such interpretation in a majority of decisions does not imply that this approach would be marginal. Autonomous interpretation was deemed not necessary owing to the nature of these cases.

The bilingual nature of the Convention was reflected in two cases. In one, the second binding language version was taken into account subsidiarily. In the other case, the ECtHR directly compared the meanings commonly attributed to the terms used and preferred the broader one: "It is true that the English word "labour" is often used in the narrow sense of manual work, but it also bears the broad meaning of the French word "travail" and it is the latter that should be adopted in the present context'. As a matter of fact, it used the text of the 'Forced Labour Convention' to support this approach. Meanwhile, the potential of the Convention's bilingual wording was not exploited at all in one other decision where the problem at hand could also have been resolved by a reference to the French term. Nevertheless, the ECtHR did correctly evaluate the substance of the slightly different phrases used in various provisions of the Convention and assigned them the same meaning. It stated specifically that the phrase 'in accordance with the law' used in Article 8 'alludes to the very same concept of lawfulness as that to which the Convention refers elsewhere when using the same or similar expressions, notably the expressions "lawful" and "prescribed by law" found in the second paragraphs of Articles 9 to 11'.

\subsection{Logical (linguistic-logical) arguments}

The set of decisions under scrutiny demonstrates no broader use of this method of interpretation. The a contrario argument is mentioned in a single case. ${ }^{126}$ This, moreover, pertained to the Court's own prior decision, rather than the legislation. As such, the case does not fall in this category, strictly. It is not true, however, that the circumstances would not favour the use of this method. It is striking that a case 
concerning adoption by a same-sex couple in Austria was not argued a contrario. Indeed, this argument would suggest itself in this case. The Court had to determine how individual countries and international law approached the possibility of child adoption by same-sex couples. While this area was covered by an international treaty (the Convention on the Adoption of Children), a number of contracting parties remained unconvinced at the time. The lack of consensus among various countries as to the resolution of this issue was clearly discernible from the following facts, in spite of the existence of the treaty: the number of State parties to the Convention on the Adoption of Children was low; many countries had no regulation on this subject in national law; and where such regulation existed, it varied fundamentally in the approach taken to the relevant issue. Thus, the solution adopted in the Convention on the Adoption of Children was not a suitable guideline for the interpretation of the Convention, as it did not reflect the state of general international law at the time.

The absence of a specific regulation in the Convention and its Protocols was noted with regard to the (non-)existence of a right of political asylum. ${ }^{127}$ According to the ECtHR, the fact that this question was not explicitly regulated reinforced the conclusion that it was the individual States that had the power to control the entry, residence, and expulsion of aliens.

Analogy was used only once, with regard to the reasoning provided earlier by the ECtHR in the same decision, when interpreting and applying some other provision. This was therefore not a matter of interpreting the law on the basis of analogy but rather a shortcut used to save the Court's time. Consequently, this case cannot be counted either. Similarly, argumentem ad absurdum was used in only one case ${ }^{128}$ to exclude the impossible and unacceptable result of interpretation.

\subsection{Domestic systemic arguments}

Contextual interpretation in a narrow and broad sense (including the so-called 'derogatory formulae') was mentioned in a majority of cases, always with a view to achieving internal 'consistency and harmony' in the interpretation and effects of the Convention or its provisions. From the qualitative point of view, the significance of contextual interpretation in a narrow and broad sense (including the so-called 'derogatory formulae'), and in fact, of all other methods of interpretation was completely outweighed by interpretation carried out on the basis of the existing case law of the ECtHR. In substance, this interpretation method formed the axis of interpretation in all the decisions of this Court, and was predominant in both quantitative and qualitative terms. It is clear that the ECtHR can benefit from its robust case law, ${ }^{129}$ but it is thus ultimately bound by its previous conclusions. Meanwhile, it has

129 Even in more recent decisions, it also considers the conclusions of the ECtHR. See Magyar Helsinki Bizottság v. Hungary. 
a foundation available for seeking effective solutions to existing and new cases, and it therefore need not rely on classical methods of interpretation. This conclusion, however, lessens the importance of contextual interpretation, which has been used quite frequently-in 20 decisions in total (in three of which, the court used the contextual interpretation in both a broad and narrow sense; in 11 cases, in a broad sense; and in six cases, in a narrow sense).

In all the cases under scrutiny, the ECtHR used its own previous rulings as pieces of a jigsaw puzzle to create an ad hoc overall image of the contents of the Convention. It is typical of its work that both interpretation and subsequent application are always conducted along a single line. In doing so, the Court works with its previous decisions in connection with the facts of the case (i.e. either to support a certain conclusion or to refute it). It was also characteristic of all the decisions assessed that they never yielded any new general and abstract rule. They ended up being yet another piece of a puzzle that might be used together with other pieces to build up a new case. The lack of effort to formulate general rules is not necessarily a problem-quite the contrary. The ECtHR thus plays its subsidiary role and reflects on the position that may be attributed to it by the Convention. It is supposed to provide protection to persons affected in individual cases, not to make the law. This fact is of great importance for the CCC and other national courts. Indeed, they should approach the rulings of the ECtHR in this spirit. They cannot be treated as general guidelines for dealing with specific matters. The facts of any given case and its overall context must always be carefully taken into account. This is where the CCC might have a perceivable main risk, as it may have knowingly overlooked this fact in some cases and inferred more from an ECtHR decision than was appropriate.

Ultimately, the way the ECtHR works with the Convention in the majority of the selected cases cannot be considered interpretation. The ECtHR does not present any general rule. It attempts to infer its meaning and impact on the specific case through individual methods of interpretation. However, the opposite was true in all the cases under scrutiny. Based on existing decisions, the ECtHR synthesises rules that it then applies in a specific case. Its approach is thus the opposite compared with standard decision-making by common courts. Nonetheless, two exceptions were found in the set of decisions under assessment where the above conclusions did not fully apply.

\subsection{External systemic and comparative law arguments}

When interpreting the Convention, the ECtHR reflects the rules of interpretation provided for in Articles 31 to 33 of the Vienna Convention of 23 May 1969 on the Law of Treaties. These rules were explicitly mentioned only once in the set of cases under scrutiny. The contents of the decisions showed that interpretation of the Convention according to the rules of the Vienna Convention was not an exception but rather a standard. This is documented by the number of decisions referred to by the ECtHR when specifying the contents of the Vienna Convention. The ECtHR has an 
elaborated and clearly defined methodology in its decisions, based on which it takes external sources of interpretation into consideration. ${ }^{130}$

The significance of the list of external authorities whose opinions or interpretation comprise a common part of a number of decisions in the set of cases under assessment, together with statements of the governments and parties to the proceedings, is unclear. Reference to these authorities might indicate that they are also considered and taken into account by the ECtHR. However, they were merely described and simply noted in a majority of the cases, without the ECtHR using them to interpret the Convention in any way. Even a mere statement that they were not relevant for some reason could have served as valuable information. Moreover, they could have affected the Court's considerations in all the cases, at least in the stage of pre-knowledge, where the judges individually and internally form their own opinions on the case at hand. As this influence was not visibly manifested in the decisions, these cases were not reflected in the qualitative and quantitative evaluation.

The effect of the rules of interpretation in the Vienna Convention is evidenced, among other things, by the clear effort of the ECtHR to provide harmonic interpretation of the Convention with respect to the other international treaties. The influence of specialised international instruments is apparent in this regard, as they have the potential to clarify the highly general Convention, to be applied in specific cases. The ECtHR works comprehensively with these international treaties. It does not limit itself only to their text, in the sense that it would interpret it itself, but also takes into account the case law of the courts responsible for their interpretation. ${ }^{31}$ Common courts, however, have very limited options and means compared with the ECtHR.

To be specific, the decisions in the analysed set included the following documents: Forced Labour Convention, Inter-American Court of Human Rights' interpretation of Article 13 of the American Convention on Human Rights, as set out in the case of Claude Reyes et al. v. Chile; Declaration of Principles of Freedom of Expression in Africa, adopted by the African Commission on Human and Peoples' Rights in 2002; International Covenant on Civil and Political Rights; the United Nations Human Rights Committee; Recommendation of the Committee of Ministers of the Council of Europe and of the The Parliamentary Assembly. ${ }^{132}$ EU law and the European Union's Charter of Fundamental Rights as well as Regulation (EC) No. 1049/2001 of the European Parliament and of the Council of 30 May 2001 were also taken into consideration.

However, the application of international treaties and other international authorities is not a matter of course, as one treaty was even explicitly rejected in one of the decisions included in the set under review. This treaty was the Convention on

130 Magyar Helsinki Bizottság v. Hungary.

131 One case reflected a ruling of the Inter-American Court of Human Rights (Magyar Helsinki Bizottság v. Hungary) and another, a judgement of the ECJ (Big Brother Watch and Others).

132 D.H. and others v. The Czech Republic. 
the Adoption of Children, and the reason for setting it aside was that the number of Contracting States was insufficient and thus not representative. As such, the contents and the objective capacity of a certain authority to convey information on the legal approach taken by individual countries to a certain social problem are relevant for reflecting a certain external authority.

References to social reality and legislation in the Member States of the Council of Europe have repeatedly appeared in the set of decisions under scrutiny. A reference was made both to the legislation ${ }^{133}$ and, together with it, to case law ${ }^{134}$ or, in general, to the approach taken by national authorities to the issue. ${ }^{135}$

From among other sources, the ECtHR worked with conclusions of the Venice Commission ${ }^{136}$ and Explanatory Report to the Council of Europe's Civil Law Convention on Corruption. ${ }^{137}$ In one of its decisions, the ECtHR referred to 'well-established international law', which enables the State to control the entry, residence, and expulsion of aliens. ${ }^{138}$ As regards non-legal, factual sources of information, the ECtHR invoked 'numerous scientific studies'. ${ }^{139}$

\subsection{Teleological/objective teleological interpretation}

Similar to the CCC, the ECtHR explicitly used the teleological method of interpretation only in a minority of cases in our set of decisions. The reasoning may indicate that the ECtHR did consider the purpose, but did not expressly admit this, nor did it reveal to what extent and in what specific way it did so. Arguments concerning the purpose of the Convention were frequently present implicitly or through the citation of the previous decisions of this court, in which this method had been used. The current analysis observed a clear reflection on the purpose of the legislation in a total of 15 of the 29 evaluated cases.

\subsection{Historical/subjective teleological interpretation}

The ECtHR took the travaux préparatoires into consideration in three cases. In one of these decisions, the ECtHR also worked with the concept of evolutive interpretation of the Convention. In quantitative and qualitative terms, the significance attached to the law-maker's intention was marginal in the cases examined. This method of interpretation was used exclusively as a supplementary means of interpretation (in conformity with the Vienna Convention). 


\subsection{Arguments based on jurisprudence/scholarly works}

Two sources of recognition of the contents of fundamental rights enshrined in the Convention are completely missing among the scrutinised decisions of the ECtHR. The first are references to professional legal literature. This marks a clear difference from the practice of the CCC, which frequently uses professional literature, albeit often in a questionable manner. Similarly, the case law of the ECtHR under assessment lacks any references to the case law of the courts of the Council of Europe's Member States. As regards professional literature pertaining to the Convention, its absence is understandable. Silence enables the ECtHR to maintain a neutral stance and resolve legal questions independent of the opinions of experts.

\subsection{Interpretation in light of general legal principles}

The use of general legal principles was rare among the decisions reviewed. Nevertheless, six of these decisions demonstrated greater consideration for the principle of legal certainty and rule of law.

\subsection{Substantive interpretation/non-legal arguments}

The ECtHR paid no attention to non-legal arguments. In the selected case law of the ECtHR, this method has not occurred in the framework of direct interpretation of the text of the Convention.

\section{Characteristics of the CCC's decision}

The structure and language of the CCC's decisions are not completely uniform. They often also differ in graphic layout. The approach applied by the individual justices is inconsistent and leaves room for individual considerations; however, the differences are not fundamental. Differences in the structure and contents can be found especially in the case of decisions made by the Plenum, on the one hand, and those rendered by individual panels, on the other hand. Within the set of decisions under scrutiny, the Plenum's decisions are characterised by their greater length. This, however, does not necessarily imply that the parts devoted to actual interpretation and application would be longer. A substantial part of the Plenum's rulings consisted of statements of third parties who were either selected and approached by the justice-rapporteur or who intervened in the proceedings based on the law or even of their own volition. Their statements de facto complemented the court's own 
activities. From this view, the decisions of the panels were better arranged and more clearly structured. ${ }^{140}$

The form of the decisions and arrangement of their individual parts are supposed to indicate that the CCC's thinking is logical, systematic, and syllogistic. This is indeed so in most cases. The Court proceeds from the text of the Constitution or the Convention, via its interpretation and subsequent application of the general rule, to the actual solution: the conclusion. The structure of legal interpretation and reasoning is simple, typically along a single line. However, one sometimes cannot avoid the impression that the decisions were written backwards: the conclusion (decision) was made first, followed by the search for the applicable legislation, and then the interpretation of the law to achieve the desired result. Such an approach is understandable, as it makes it possible to address specific human problems and stories. However, it also entails the risk of disrupting the whole system in other subsequent cases. These problems are avoided in practice using extra-legal means. Justices tend to consult informally other justices of the CCC who specialise in the relevant fields of law on the possible impacts of non-standard solutions on sub-constitutional law. The latter thus have the opportunity to talk their peers out of their well-meant intentions before any damage is done.

The language of the CCC's decisions creates a neutral, objective, rational, and logical impression of the way the Court makes its rulings. The CCC refers to itself as a third-party institution, while using authoritative phrases suggesting subconsciously that the CCC's conclusions are not open to debate. Should someone nevertheless want to argue, they are met with phrases such as 'the above-cited judgement [...] clearly declared that...', which are supposed to 'clearly' avoid any debate. This is unfortunate, especially if this approach is combined with the possibility of deciding a case based on an opinion held by only two justices (in a panel), the duty to follow earlier decisions, and certain unwillingness to change previous conclusions by presenting them to the Plenum. A small number of people-who are not asked to bear any political responsibility-also have an excessive space to influence life in society.

The intended addressees of decisions rendered by the CCC are difficult to define in view of the variety of styles used by the Court. Subjectively, the CCC stands out among the top Czech courts because of the clarity, clear structure, and comprehensibility of its decisions. Nonetheless, the ordinary citizen—the complainant-will not be their direct addressee or reader. Not that the citizen would be unable to grasp the meaning of the CCC's conclusions, but the language used by the CCC is relatively professional and sophisticated for a layman to be able to understand fully the way the CCC thinks and its individual conclusions. The style used by the CCC is often pseudo-academic, which probably owes to the fact that many of its justices and their assistants have an academic background. The academic character relates not only to the regular use of professional literature by the court but also to the layers of the individual arguments 
and the way they are explained. However, the use of professional literature is random and unscientific in that it serves as a shortcut to support and explain the CCC's conclusions and not as a basis for scientific discussion and evaluation.

Although the Court's decisions are addressed to experts in law, the CCC often, once again academically or even in a scholarly manner, explains its conclusions and certain phrases, especially those in Latin, and translates them into Czech or, on the contrary, provides a German or English equivalent along with a Czech term. Legal practitioners do not write this way-there is no sense in explaining such notions to experts who already know them well. A similar style of writing is characteristic of school textbooks and certain professional articles.

The target group of the CCC's decisions is relatively wide; along with the parties' lawyers, it also includes courts and other public authorities, including the legislature. The CCC's decisions are typical for their explanatory and persuasive style, which aims to explain the logic of the solution adopted by the CCC, especially in relation to courts. Nonetheless, despite the somewhat authoritative nature of this approach, the CCC seems willing to enter into a dialogue with other courts and respond to suggestions and ideas.

The formal academic style of the CCC's rulings is only occasionally disrupted by reflections on classical literature, used by the justices to bring the contents of their decisions closer to people. At the same time, they make it easier for external observers to understand the way the justices think and explain the values they believe in. They also serve as proof that justices and their assistants are erudite people. However, a real space for the presentation of the justices' own values and opinions are dissenting opinions, and the justices indeed like to use the options these channels provide.

\section{Quantitative Assessment}

\subsection{Case law of the Czech Constitutional Court in numbers}

The delimitation of the arguments and their quantitative assessment can only be relative as the methods often overlap in practice; occasionally, they are present but not apparent. ${ }^{141}$

The use of the grammatical method of interpretation based on the ordinary meaning of the Constitution and Charter was insignificant in the selected 30 decisions of the CCC. The CCC has not used this method explicitly in any of them. Simple conceptual dogmatic interpretation was deployed in 17 cases and interpretation on the basis of legal principles in two. Nevertheless, the CCC simultaneously and regularly used interpretation of the Constitution on the basis of its previous case law. 
Thus, the importance and significance of the grammatical method of interpretation (and of other methods as well) was lowered.

Logical argumentum a minore ad maius was used twice (6,66\%), but only once to interpret a fundamental right (3,33\%). A similar situation was with the argumentum $a$ maiore ad minus, which was used only once (3,33\%), to interpret a fundamental right. Argumentum ad absurdum appeared in four $(13,33 \%)$ cases, and argumentum a contrario in two $(6,66 \%)$ of them. Analogies were also rare, found in only four $(13,33 \%)$ cases. The principle of effectiveness was deployed three times (10\%). Meanwhile, contextual interpretation in a narrow sense was deployed in nine decisions (30\%), and that in a broad sense, in 14 decisions (47\%). Interpretation of constitutional norms on the basis of domestic staturory law was deployed in three (10\%) cases in total.

At the other end of the spectrum are those methods that occur regularly in the case law of the CCC. Comparative interpretation occurred in $50 \%$ of cases. Argumentation based on jurisprudence was used in half of the cases (50\%) as well, and interpretation on the basis of the case law of the CCC or the Convention (as interpreted by the ECtHR) both had $100 \%$ occurrence. Only once $(3,33 \%)$ the CCC referred to any other international court than the ECtHR or ECJ. Similarly, the CCC referred only once $(3,33 \%)$ to any other international treaty other than the European Convention on Human Rights or EU Charter in order to interpret the fundamental right as protected by the Charter. Meanwhile, in five $(16,65 \%)$ cases, the CCC took into account other international treaties. Once, the EU Charter was reflected. Other external sources were used in three (10\%) cases. In all the selected cases, the CCC had an intention to interpret the same rights protected by the Charter and the Convention in the same way. However, in one case (3,33\%), it took into account the international character of the Convention and possible different meanings of the terms it uses.

When it comes to the interpretation of constitutional norms on the basis of domestic statutory law, the practice of the CCC is rather ambivalent. In two cases $(6,66 \%)$, the CCC fully accepted statutory law for the purposes of interpreting a fundamental right; in one case, it did not. Three occurrences $(10 \%)$ had the interpretation of the Constitution based on the case law of common courts. Meanwhile, teleological interpretation was deployed in seven cases (23,33\%); nevertheless, the significance and importance of this method shall not be underestimated. Quite frequent was also the interpretation in light of general legal principles, found in $70 \%$ of the cases, although it was typically not a decisive one. Non-legal arguments were used in $16,66 \%$ of cases.

\subsection{Case law of the the EctHR and ECJ in numbers}

The use of the grammatical method of interpretation of the Convention and the Charter based on the ordinary meaning of words was significant in three decisions (10,34\%). Simple conceptual dogmatic/doctrinal interpretation was used in 25 cases $(86,20 \%)$ and interpretation on the basis of legal principles, in three decisions (10,34\%), all out of the decisions of both the ECtHR and the ECJ. 
Logical arguments were rather rare; they were used five cases (17,24\%). Meanwhile, domestic systemic arguments were frequently used. Contextual interpretation in a narrow and broad sense was deployed in 20 decisions $(68,96 \%)$. Interpretation based on the existing case law of the ECtHR or ECJ tended to be dominant, occurring in all 29 cases (100\%). External systemic and comparative law arguments were also quite common as they were cumulatively used in eight cases $(27,58 \%)$.

The objective teleological method of interpretation was used in 15 cases $(51,72 \%)$, whereas subjective teleological interpretation appeared in three cases (10,34\%). Arguments based on jurisprudence were not used at all, nor was substantive interpretation. Interpretation using general principles occurred in six cases $(20,69 \%)$.

Only one of three decisions of the ECJ dealt explicitly with human rights. This court applied the grammatical and teleological methods of interpretation only once. It also referred to its previous case law as well as to the case law of the EctHR and reflected the principle of proportionality in only one case. In two cases, it adopted a rather dogmatic approach, simply stating the existence of a right without further analysis. This court also took a different perspective from the ECtHR. The human rights perspective is not the first priority. The context of the sub-constitutional law is also reflected; this law is in the centre of interest of the ECJ, whereas the ECtHR naturally does not take it directly into account. Therefore, the ECJ's interpretation in the field of human rights has not been nearly as sophisticated as it has been in the judgements of the ECtHR. However, the ECJ took into account the case law of the ECtHR and worked with it in a similar way to its own.

\section{Conclusion}

Although the total number of Constitutional Court decisions examined was relatively small and potentially unrepresentative, the statistics are broadly in line with what is reported in the literature. Kühn's study of the Constitutional Court's decisions reached the same conclusions and significantly differed only in the case of teleological interpretation. This difference could be easily explained. The selection of the present cases was quite specific because of the conditions set by the research design, whereas Kühn had a free choice over a longer period of time. As a consequence of the research design, the teleological method of interpretation has been de facto substituted by references to ECtHR decisions. ${ }^{142}$

Similarities and differences can be noted in the interpretation provided by the CCC and the ECtHR, and fundamental differences between the CCC and the ECJ. In the case of the ECJ, however, the number of decisions included in the present set was too small to allow for objective and general conclusions. As to similarities, it is 
clear that the ECtHR relies in its decision-making on robust existing case law, which serves primarily as the starting point for its considerations. Prior decisions are an absolutely predominant means of identifying the contents of the law. All other methods of interpretation are only auxiliary in the decisions under scrutiny. The CCC, too, has reached a stage where it can work with a large body of its own case law; its work is similar to that of the ECtHR in this sense. The original differences between the two courts are gradually subsiding in this regard. However, the CCC more often draws on external sources, especially the case law of the ECtHR. The latter is like its older brother and thus has a considerable influence on the way the CCC makes its decisions. The ECtHR has no such close relation with any other court.

Minor differences can be observed in the approach of the two courts to prior case law. The ECtHR is aware of its subsidiary role and therefore uses its previous rulings with greater sensitivity towards the facts of the case and social, legal, and political reality in a state concerned. For this court, its judgements do not serve as means of broadening the impact of the Convention but rather as means of resolving new individual problems, always with all due respect to the states and their national identities. Thus, the margin of appreciation doctrine is frequently used by this court, a legal doctrine unknown to decisions of the CCC. Meanwhile, the CCC typically adopts an extensive approach to earlier case law (both its own and that of the ECtHR), to generalise it and, at the same time, take lesser consideration of the facts of the case, while being more willing to apply prior decisions to new, unresolved cases. This is undoubtedly also supported by the Czech tradition of 'legal sentences' or 'headnotes', which provide a general conclusion on each case. They are used as an extension of written law and, in Czech legal practice, are commonly applied without any greater link to the original facts of the case. ${ }^{143}$

Another difference lies in the greater willingness of the CCC to use other methods of interpretation. What the two courts have in common, however, are the rather marginal effects of logical (linguistic-logical) arguments and surprisingly also minor explicit use of objective or subjective teleological interpretation, which is downright typical of the ECJ. This difference between the CCC and the ECtHR probably owes to the fact that despite the mentioned robust case law of the two courts, a number of individual questions have yet to be expressly addressed, especially in the Czech Republic. More space is thus left for other methods of interpretation. Over time, the CCC may also become 'bound' by its previous case law, just like the ECtHR.

Of the two courts, it is the ECtHR that gives the impression of being a genuine court. In contrast, the CCC also plays a political role-along with its judicial function-in the sense that it actively influences the functioning of the State and society (i.e. also forms politics). In aggregate, some of the CCC's justices find inspiration in the way the ECtHR works and strive to follow it as much as possible. 


\section{Bibliography}

CHMEL, J. (2017) 'Zpravodajové a senáty: Vliv složení senátu na rozhodování Ústavního soudu České republiky o ústavních stížnostech', Časopis pro právní vědu a praxi, Vol. 4, pp. 739-758.

DumbrovskÝ, T. (2012) 'Soudní spolupráce v Evropském ústavním prostoru po východním rozšíření Evropské unie', Acta Universitatis Carolinae Iuridica, Vol. 2, pp. 51-73.

HAMULÁK, O. (2011) 'Flexibilita ústavního pořádku, právo Evropské unie a marginalia $\mathrm{k}$ Listině základních práv Evropské unie' in Mlsna, P. (ed.) Ústava ČR - vznik, vývoj a perspektivy. Praha: Leges.

HAMULÁK, O. (2014) 'The Unbearable Lightness of Being Guardian of the Constitution (Revolt and Revolution Dilemma in the Approach of Czech Constitutional Court Vis-à-Vis EU and Supranational Legal Order)', European studies - The Review of European Law, Economics and Politics, Vol. 1, pp. 119-129.

KüHN, Z. (2017) 'The Constitutional Court of the Czech Republic' in Jakab, A., Dyevre, A., Itzcovich, G. (eds.) Comparative Constitutional Reasoning. Cambridge: Cambridge University Press.

Novak, M. (2001) 'Ústavní soud mezi právem a politikou', Právník, Vol. 5, pp. 421-439.

Petrov, J. (2019) 'Vnitrostátní soudy a způsoby argumentace judikaturou ESLP', Právník, 158(2), pp. 163-243.

SEhnÁlek, D., STEhlík, V. (2019) 'European "Judicial Monologue” of the Czech Constitutional Court - a Critical Review of its approach to the Preliminary Ruling Procedure', International and Comparative Law Review, 19(2), pp. 181-199.

SEHNÁlEK, D. (2019) 'Specifika výkladu práva Evropské unie a jeho vnitrostátní důsledky'. Praha: C.H.Beck.

Tотн, Z. (2016) 'The Methods of Statutory Interpretation in the Practice of the High Courts of Hungary', Annales Universitatis Mariae Curie-Sklodowska, I(M), pp. 173-201.

TVRDÍKOVÁ, L (2020) 'Důležitost kontextu při používání judikatury', Časopis pro právní vědu a praxi, 2(4), pp. 587-612.

WAgnerovÁ, E., DostÁL, M., LANGÁŠEK, T., PospíšIL, I. (2007) Zákon o Ústavním soudu s komentářem. Praha: Wolters Kluwer.

ZEMÁNEK, J. (2016) 'European Constitutionalism in the Context of Judicial Dialogue' in Göttinger, V. (ed.) Evropský konstitucionalismus v kontextu soudního dialogu. Brno: Ústavní soud. 


\section{List of selected decisions}

\begin{tabular}{|c|c|c|}
\hline 1. & $\begin{array}{l}\text { Decision Pl.ÚS } 17 / 10 \text { of the Constitu- } \\
\text { tional Court }\end{array}$ & $\begin{array}{l}\text { Salov v. Ukraine, Application no. 65518/01, } \\
\text { judgment of } 6 \text { Septembre } 2005\end{array}$ \\
\hline 2. & $\begin{array}{l}\text { Decision Pl.ÚS } 49 / 10 \text { of the Constitu- } \\
\text { tional Court }\end{array}$ & $\begin{array}{l}\text { D.H. and others v. the Czech Republic, Appli- } \\
\text { cation no. 57325/00, judgment of } 13 \text { November } \\
2007\end{array}$ \\
\hline 3. & $\begin{array}{l}\text { Decision IV.ÚS } 1521 / 10 \text { of the Con- } \\
\text { stitutional Court }\end{array}$ & $\begin{array}{l}\text { Andrea Francovich and Danila Bonifaci and } \\
\text { others v Italian Republic, C-6/90 and C-9/90, } \\
\text { judgment of } 19 \text { November } 1991\end{array}$ \\
\hline 4. & $\begin{array}{l}\text { Decision Pl. ÚS 26/11 of the Consti- } \\
\text { tutional Court }\end{array}$ & $\begin{array}{l}\text { Ternovszky v. Hungary, Application no. } \\
\text { 67545/09, judgment of } 14 \text { December } 2010\end{array}$ \\
\hline 5. & $\begin{array}{l}\text { Decision Pl.ÚS } 1 / 12 \text { of the Constitu- } \\
\text { tional Court }\end{array}$ & $\begin{array}{l}\text { Van der Mussele v. Belgium, Application no. } \\
\text { 8919/80, judgment of } 23 \text { November } 1983\end{array}$ \\
\hline 6. & $\begin{array}{l}\text { Decision .ÚS } 2219 / 12 \text { of the Consti- } \\
\text { tutional Court }\end{array}$ & $\begin{array}{l}\text { Sergey Glaser v. the Czech Republic, Appli- } \\
\text { cation no. 55179/00, judgment of } 14 \text { October } \\
2008\end{array}$ \\
\hline 7. & $\begin{array}{l}\text { Decision Pl.ÚS } 16 / 14 \text { of the Constitu- } \\
\text { tional Court }\end{array}$ & $\begin{array}{l}\text { Leyla Şahin v. Turkey, Application no. } \\
\text { 44774/98, judgment of } 10 \text { November } 2005\end{array}$ \\
\hline 8. & $\begin{array}{l}\text { Decision III. ÚS } 3457 / 14 \text { of the Con- } \\
\text { stitutional Court }\end{array}$ & $\begin{array}{l}\text { Financial Times ltd and others v. the United } \\
\text { Kingdom, Application no. 821/03, judgment of } \\
15 \text { December } 2009\end{array}$ \\
\hline 9. & $\begin{array}{l}\text { Decision Pl.ÚS } 7 / 15 \text { of the Constitu- } \\
\text { tional Court }\end{array}$ & $\begin{array}{l}\text { Fretté v. France, Application no. 36515/97, } \\
\text { judgment of } 26 \text { February } 2002\end{array}$ \\
\hline 10. & $\begin{array}{l}\text { Decision I. ÚS } 2617 / 15 \text { of the Consti- } \\
\text { tutional Court }\end{array}$ & $\begin{array}{l}\text { Guja v. Moldova, Application no. 14277/04, } \\
\text { judgment of } 12 \text { February } 2008\end{array}$ \\
\hline 11. & $\begin{array}{l}\text { Decision I. ÚS } 2769 / 15 \text { of the Consti- } \\
\text { tutional Court }\end{array}$ & $\begin{array}{l}\text { Miracle Europe kft v. Hungary, Application no. } \\
57774 / 13 \text {, judgment of } 12 \text { January } 2016\end{array}$ \\
\hline 12. & $\begin{array}{l}\text { Decision Pl. ÚS } 26 / 16 \text { of the Consti- } \\
\text { tutional Court }\end{array}$ & $\begin{array}{l}\text { Digital Rights Ireland and Seitlinger and } \\
\text { Others, C-293/12, judgment of } 8 \text { April } 2014\end{array}$ \\
\hline 13. & $\begin{array}{l}\text { Decision Pl.ÚS } 30 / 16 \text { of the Consti- } \\
\text { tutional Court }\end{array}$ & $\begin{array}{l}\text { Zarb Adami v. Malta, Application no. } \\
\text { 17209/02, judgment of } 20 \text { June } 2006\end{array}$ \\
\hline 14. & $\begin{array}{l}\text { Decision .ÚS } 425 / 16 \text { of the Constitu- } \\
\text { tional Court }\end{array}$ & $\begin{array}{l}\text { M.S.S. v. Belgium and Greece, Application no. } \\
\text { 30696/09, judgment of } 21 \text { January } 2011\end{array}$ \\
\hline
\end{tabular}




\begin{tabular}{|c|c|c|}
\hline 15. & $\begin{array}{l}\text { Decision I. ÚS } 630 / 16 \text { of the Con- } \\
\text { stitutional Court }\end{array}$ & $\begin{array}{l}\text { Jabari v. Turkey, Application no. 40035/98, } \\
\text { judgment of } 11 \text { July } 2000\end{array}$ \\
\hline 16. & $\begin{array}{l}\text { Decision IV. ÚS } 1378 / 16 \text { of the Con- } \\
\text { stitutional Court }\end{array}$ & $\begin{array}{l}\text { Magyar Helsinki Bizottság v. Hungary, Appli- } \\
\text { cation no. 18030/11, judgment of } 8 \text { November } \\
2016\end{array}$ \\
\hline 17. & $\begin{array}{l}\text { Decision I.ÚS } 1764 / 16 \text { of the Consti- } \\
\text { tutional Court }\end{array}$ & $\begin{array}{l}\text { C. v. Finland, Application no. 18249/02, } \\
\text { judgment of } 9 \text { May } 2006\end{array}$ \\
\hline 18. & $\begin{array}{l}\text { Decision I.ÚS 1860/16 of the Consti- } \\
\text { tutional Court }\end{array}$ & $\begin{array}{l}\text { Schatschaschwili v. Germany, Application no. } \\
\text { 9154/10, judgment of } 15 \text { December } 2015\end{array}$ \\
\hline 19. & $\begin{array}{l}\text { Decision IV. ÚS } 2326 / 16 \text { of the Con- } \\
\text { stitutional Court }\end{array}$ & $\begin{array}{l}\text { R \& L, s.r.o. and others v. the Czech Re- } \\
\text { public, Application nos. } 37926 / 05,25784 / 09 \text {, } \\
36002 / 09,44410 / 09 \text { and 65546/09, judgment } \\
\text { of } 3 \text { July } 2014\end{array}$ \\
\hline 20. & $\begin{array}{l}\text { Decision I. ÚS } 3226 / 16 \text { of the Con- } \\
\text { stitutional Court }\end{array}$ & $\begin{array}{l}\text { Mennesson v. France, Application no. } \\
65192 / 11 \text {, judgment of } 26 \text { June } 2014\end{array}$ \\
\hline 21. & $\begin{array}{l}\text { Decision Pl. ÚS } 36 / 17 \text { of the Consti- } \\
\text { tutional Court }\end{array}$ & $\begin{array}{l}\text { Horváth and spo v. Hungary, Application no. } \\
11146 / 11 \text {, judgment of } 29 \text { January } 2013\end{array}$ \\
\hline 22. & $\begin{array}{l}\text { Decision Pl.ÚS } 45 / 17 \text { of the Consti- } \\
\text { tutional Court }\end{array}$ & $\begin{array}{l}\text { Big Brother Watch and others v. the United } \\
\text { Kingdom, Application nos. 58170/13, 62322/14 } \\
\text { and 24960/15, judgment of } 5 \text { September 2017 }\end{array}$ \\
\hline 23. & $\begin{array}{l}\text { Decision III.ÚS } 1434 / 17 \text { of the Con- } \\
\text { stitutional Court }\end{array}$ & $\begin{array}{l}\text { Dhahbi v. Italy, Application no. 17120/09, } \\
\text { judgment of } 8 \text { April } 2014\end{array}$ \\
\hline 24. & $\begin{array}{l}\text { Decision IV. ÚS } 3359 / 17 \text { of the Con- } \\
\text { stitutional Court }\end{array}$ & $\begin{array}{l}\text { Baka v. Hungary, Application no. 20261/12, } \\
\text { judgment of } 23 \text { June } 2016\end{array}$ \\
\hline 25. & $\begin{array}{l}\text { Decision II. ÚS } 3432 / 17 \text { of the Con- } \\
\text { stitutional Court }\end{array}$ & $\begin{array}{l}\text { Ullens de Schooten and Rezabek v. Belgium, } \\
\text { Application nos. } 3989 / 07 \text { and 38353/07, } \\
\text { judgment of } 20 \text { September } 2011\end{array}$ \\
\hline 26. & $\begin{array}{l}\text { Decision III.ÚS } 4071 / 17 \text { of the Con- } \\
\text { stitutional Court }\end{array}$ & $\begin{array}{l}\text { Morice v. France, Application no. 29369/10, } \\
\text { judgment of } 23 \text { April } 2015\end{array}$ \\
\hline 27. & $\begin{array}{l}\text { Decision II. ÚS } 819 / 18 \text { of the Consti- } \\
\text { tutional Court }\end{array}$ & $\begin{array}{l}\text { Agrobet CZ, s.r.o. v Finanční úřad pro } \\
\text { Středočeský kraj, C-446/18, judgment of } 14 \\
\text { May } 2020\end{array}$ \\
\hline 28. & $\begin{array}{l}\text { Decision II. ÚS } 3212 / 18 \text { of the Con- } \\
\text { stitutional Court }\end{array}$ & $\begin{array}{l}\text { Feference to the established case law of the } \\
\text { ECHR without mentioning directly the exact } \\
\text { source of the citation - the source is cited indi- } \\
\text { rectly via several books }\end{array}$ \\
\hline
\end{tabular}


29. Decision IV. ÚS 3500/18 of the Constitutional Court

30. Decision Pl. ÚS $6 / 20$ of the Constitutional Court
Orlen Lietuva ltd. v. Lithuania, Application no. 45849/13, judgment of 29 January 2019

X And others v. Austria, Application no. 19010/07, judgment of 19 February 2013 
DAVID SEHNÁLEK

\begin{tabular}{|c|c|c|c|c|c|}
\hline \multicolumn{3}{|c|}{ Methods } & $\begin{array}{c}\text { Frequency } \\
\text { (number) }\end{array}$ & $\begin{array}{c}\text { Frequency } \\
\text { (number and \%) }\end{array}$ & $\begin{array}{l}\text { Main types frequency } \\
\text { (number and \%) }\end{array}$ \\
\hline \multirow{5}{*}{1} & \multirow{2}{*}{$1 / \mathrm{A}$} & a) & 0 & $0 \%$ & \multirow{5}{*}{17 (57\%) } \\
\hline & & b) & 0 & $0 \%$ & \\
\hline & \multirow{2}{*}{$1 / \mathrm{B}$} & a) & 17 & $9 \%$ & \\
\hline & & b) & 2 & $1 \%$ & \\
\hline & \multicolumn{2}{|c|}{$1 / \mathrm{C}$} & 0 & $0 \%$ & \\
\hline \multirow{6}{*}{2} & \multicolumn{2}{|c|}{$2 / \mathrm{A}$} & 1 & $1 \%$ & \multirow{6}{*}{$15(50 \%)$} \\
\hline & \multicolumn{2}{|c|}{$2 / \mathrm{B}$} & 1 & $1 \%$ & \\
\hline & \multicolumn{2}{|c|}{$2 / \mathrm{C}$} & 4 & $2 \%$ & \\
\hline & \multicolumn{2}{|c|}{$2 / \mathrm{D}$} & 2 & $1 \%$ & \\
\hline & \multicolumn{2}{|c|}{$2 / \mathrm{E}$} & 4 & $2 \%$ & \\
\hline & \multicolumn{2}{|c|}{$2 / \mathrm{F}$} & 3 & $2 \%$ & \\
\hline \multirow{8}{*}{3} & \multicolumn{2}{|c|}{$3 / \mathrm{A}$} & 12 & $7 \%$ & \multirow{8}{*}{$30(100 \%)$} \\
\hline & \multicolumn{2}{|c|}{ 3/B } & 3 & $2 \%$ & \\
\hline & \multirow{3}{*}{$3 / \mathrm{C}$} & a) & 30 & $17 \%$ & \\
\hline & & b) & 0 & $0 \%$ & \\
\hline & & c) & 0 & $0 \%$ & \\
\hline & \multirow{3}{*}{$3 / \mathrm{D}$} & a) & 0 & $0 \%$ & \\
\hline & & b) & 3 & $2 \%$ & \\
\hline & & c) & 0 & $0 \%$ & \\
\hline \multirow{4}{*}{4} & \multicolumn{2}{|c|}{ 4/A } & 1 & $1 \%$ & \multirow{4}{*}{30 (100\%) } \\
\hline & \multicolumn{2}{|c|}{ 4/B } & 30 & $17 \%$ & \\
\hline & \multicolumn{2}{|c|}{$4 / \mathrm{C}$} & 15 & $8 \%$ & \\
\hline & \multicolumn{2}{|c|}{ 4/D } & 4 & $2 \%$ & \\
\hline \multicolumn{3}{|c|}{5} & 7 & $4 \%$ & $23(4 \%)$ \\
\hline \multirow{4}{*}{6} & \multicolumn{2}{|c|}{$6 / \mathrm{A}$} & 0 & $0 \%$ & \\
\hline & \multicolumn{2}{|c|}{$6 / B$} & 0 & $0 \%$ & 0000 \\
\hline & & & 0 & $0 \%$ & $0(0 \%)$ \\
\hline & & & 0 & $0 \%$ & \\
\hline & 7 & & 15 & $8 \%$ & $15(50 \%)$ \\
\hline & 8 & & 21 & $12 \%$ & $21(70 \%)$ \\
\hline & 9 & & 3 & $2 \%$ & $3(10 \%)$ \\
\hline
\end{tabular}


1. Grammatical (textual) interpretation

$1 / A$. Interpretation based on ordinary meaning

a) Semantic interpretation

b) Syntactic interpretation

1/B. Legal professional (dogmatic) interpretation

a) Simple conceptual dogmatic (doctrinal) interpretation (regarding either constitutional or other branches of law)

b) Interpretation on the basis of legal principles of statutes or branches of law

$1 / C$. Other professional interpretation (in accordance with a non-legal technical meaning)

2. Logical (linguistic-logical) arguments

2/A. Argumentum a minore ad maius: inference from smaller to bigger

$2 / B$. Argumentum a maiore ad minus: inference from bigger to smaller

2/C. Argumentum ad absurdum

2/D. Argumentum a contrario/arguments from silence

2/E. Argumentum a simili, including analogy

2/F. Interpretation according to other logical maxims

3. Domestic systemic arguments (systemic or harmonising arguments)

3/A. Contextual interpretation

a) In narrow sense

b) In broad sense (including 'derogatory formulae': lex superior derogat legi inferiori, lex specialis derogat legi generali, lex posterior derogat legi priori)

$3 / B$. Interpretation of constitutional norms on the basis of domestic statutory law (acts, decrees)

$3 / C$. Interpretation of fundamental rights on the basis of jurisprudence of the constitutional court

a) References to specific previous decisions of the constitutional court (as 'precedents')

b) Reference to the 'practice' of the constitutional court

c) References to abstract norms formed by the constitutional court

$3 / D$. Interpretation of fundamental rights on the basis of jurisprudence of ordinary courts

a) Interpretation referring to the practice of ordinary courts

b) Interpretation referring to individual court decisions

c) Interpretation referring to abstract judicial norms

3/E. Interpretation of fundamental rights on the basis of normative acts of other domestic state organs

4. External systemic and comparative law arguments

4/A. Interpretation of fundamental rights on the basis of international treaties

$4 / B$. Interpretation of fundamental rights on the basis of individual case decisions or jurisprudence of international fora

4/C. Comparative law arguments

a) References to concrete norms of a particular foreign legal system (constitution, statutes, decrees)

b) References to decisions of the constitutional court or ordinary court of a particular foreign legal system

c) General references to 'European practice', 'principles followed by democratic countries', and similar nonspecific justificatory principles

4/D. Other external sources of interpretation (e.g. customary international law, ius cogens)

5. Teleological/objective teleological interpretation (based on the objective and social purpose of the legislation)

6. Historical/subjective teleological interpretation (based on the intention of the legislator):

$6 / A$. Interpretation based on ministerial/proposer justification

$6 / B$. Interpretation based on draft materials

$6 / C$. Interpretation referring, in general, to the 'intention, will of the constitution-maker'

$6 / D$. Other interpretation based on the circumstances of making or modifying/amending the constitution or the constitutional provision (fundamental right) in question

7. Interpretation based on jurisprudence (references to scholarly works)

8. Interpretation in light of general legal principles (not expressed in statutes)

9. Substantive interpretation referring directly to generally accepted non-legal values 